Prepared in cooperation with the Idaho Department of Water Resources

\title{
Stream Seepage and Groundwater Levels, Wood River Valley, South-Central Idaho, 2012-13
}

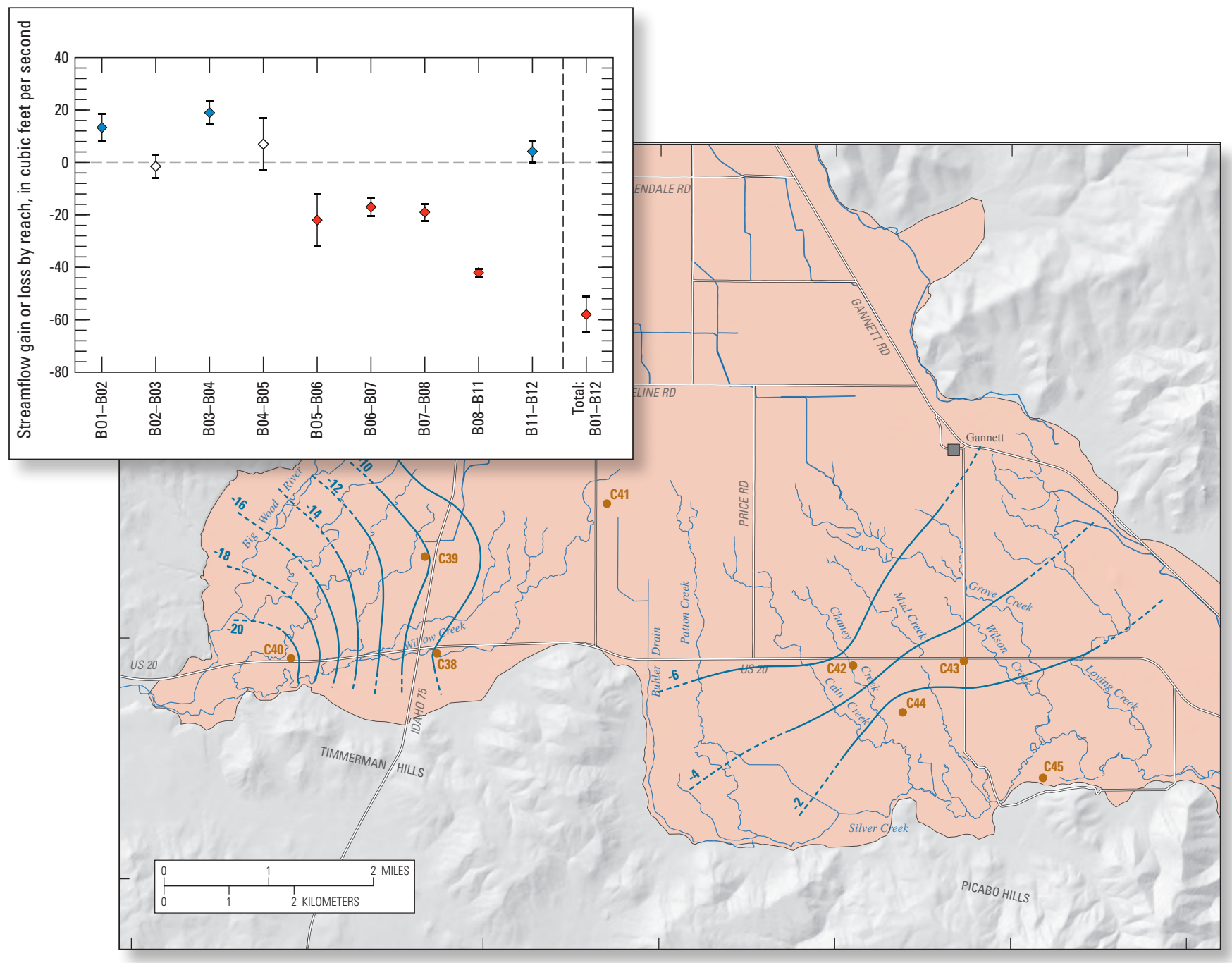

Scientific Investigations Report 2014-5151 
Cover: Graph showing measured streamflow gain or loss by reach and map showing changes in potentiometric-surface altitude of the confined aquifer, Wood River Valley aquifer system, south-central Idaho. 


\section{Stream Seepage and Groundwater Levels, Wood River Valley, South-Central Idaho, 2012-13}

By James R. Bartolino

Prepared in cooperation with the Idaho Department of Water Resources

Scientific Investigations Report 2014-5151 


\title{
U.S. Department of the Interior SALLY JEWELL, Secretary
}

\section{U.S. Geological Survey Suzette M. Kimball, Acting Director}

\author{
U.S. Geological Survey, Reston, Virginia: 2014
}

For more information on the USGS - the Federal source for science about the Earth, its natural and living resources, natural hazards, and the environment, visit http://www.usgs.gov or call 1-888-ASK-USGS.

For an overview of USGS information products, including maps, imagery, and publications, visit http://www.usgs.gov/pubprod

To order this and other USGS information products, visit http://store.usgs.gov

Any use of trade, firm, or product names is for descriptive purposes only and does not imply endorsement by the U.S. Government.

Although this information product, for the most part, is in the public domain, it also may contain copyrighted materials as noted in the text. Permission to reproduce copyrighted items must be secured from the copyright owner.

Suggested citation:

Bartolino, J.R., 2014, Stream seepage and groundwater levels, Wood River Valley, south-central Idaho, 2012-13:

U.S. Geological Survey Scientific Investigations Report 2014-5151, 34 p., http://dx.doi.org/10.3133/sir20145151.

ISSN 2328-0328 (online) 


\section{Contents}

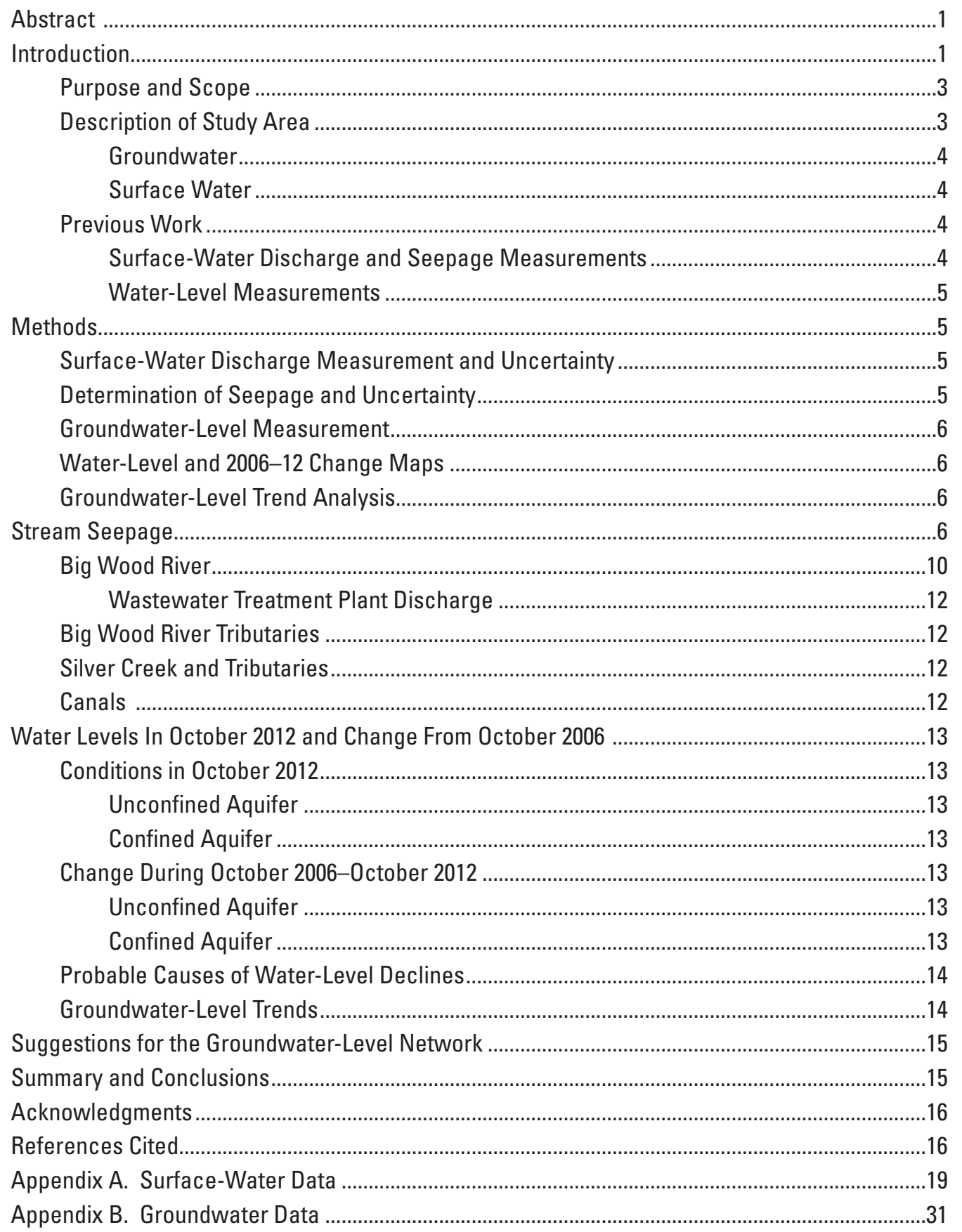




\section{Plates}

[Available online only at http://pubs.usgs.gov/sir/2014/5151/.]

1. Map showing water-table altitude of the unconfined aquifer, Wood River Valley aquifer system, south-central Idaho, October 2012.

2. Maps showing potentiometric-surface altitude of the confined aquifer, Wood River Valley aquifer system, south-central Idaho, October 2012; and, changes in the potentiometric-surface altitude of the confined aquifer, Wood River Valley aquifer system, south-central Idaho, October 2006 to October 2012.

3. Map showing changes in the water-table altitude of the unconfined aquifer, Wood River Valley aquifer system, south-central Idaho, October 2006 to October 2012.

\section{Figures}

1. Map showing locations of communities, selected U.S. Geological Survey streamgages, weather stations, wastewater-treatment plant discharge points, and other features, Wood River Valley, south-central Idaho.

2. Map showing stream-discharge measurement sites, Wood River Valley, south-central Idaho, August and October 2012, and March 2013

3. Graphs showing measured streamflow gain or loss by reach, Big Wood River, Wood River Valley, south-central Idaho, 2012-13

\section{Table}

1. Stream discharge measurement sites and measurement conditions, Wood River Valley, south-central Idaho, August 2012, October 2012, and March 2013. 
Conversion Factors, Datums, and Abbreviations and Acronyms

\section{Conversion Factors}

Inch/Pound to SI

\begin{tabular}{|c|c|c|}
\hline Multiply & By & To obtain \\
\hline \multicolumn{3}{|c|}{ Length } \\
\hline inch (in.) & 2.54 & centimeter $(\mathrm{cm})$ \\
\hline inch (in.) & 25.4 & millimeter $(\mathrm{mm})$ \\
\hline foot $(\mathrm{ft})$ & 0.3048 & meter $(\mathrm{m})$ \\
\hline mile (mi) & 1.609 & kilometer (km) \\
\hline \multicolumn{3}{|c|}{ Flow rate } \\
\hline cubic foot per second $\left(\mathrm{ft}^{3} / \mathrm{s}\right)$ & 0.02832 & cubic meter per second $\left(\mathrm{m}^{3} / \mathrm{s}\right)$ \\
\hline
\end{tabular}

\section{Datums}

Vertical coordinate information is referenced to the North American Vertical Datum of 1988 (NAVD 88).

Horizontal coordinate information is referenced to the North American Datum of 1983 (NAD 83).

Altitude, as used in this report, refers to distance above the vertical datum.

\section{Abbreviations and Acronyms}

$\begin{array}{ll}\text { ADV } & \text { acoustic Doppler velocimeter } \\ \text { EPA } & \text { U.S. Environmental Protection Agency } \\ \text { GIS } & \text { geographic information system } \\ \text { GWMA } & \text { Ground Water Management area } \\ \text { IDWR } & \text { Idaho Department of Water Resources } \\ \text { USGS } & \text { U.S. Geological Survey } \\ \text { UWRMD } & \text { Upper Wood Rivers Measurement District } \\ \text { WWTP } & \text { wastewater-treatment plant }\end{array}$





\title{
Stream Seepage and Groundwater Levels, Wood River Valley, South-Central Idaho, 2012-13
}

\author{
By James R. Bartolino
}

\section{Abstract}

Stream discharge and water levels in wells were measured at multiple sites in the Wood River Valley, south-central Idaho, in August 2012, October 2012, and March 2013, as a component of data collection for a groundwater-flow model of the Wood River Valley aquifer system. This model is a cooperative and collaborative effort between the U.S. Geological Survey and the Idaho Department of Water Resources.

Stream-discharge measurements for determination of seepage were made during several days on three occasions: August 27-28, 2012, October 22-24, 2012, and March 27-28, 2013. Discharge measurements were made at 49 sites in August and October, and 51 sites in March, on the Big Wood River, Silver Creek, their tributaries, and nearby canals.

The Big Wood River generally gains flow between the Big Wood River near Ketchum streamgage (13135500) and the Big Wood River at Hailey streamgage (13139510), and loses flow between the Hailey streamgage and the Big Wood River at Stanton Crossing near Bellevue streamgage (13140800). Shorter reaches within these segments may differ in the direction or magnitude of seepage or may be indeterminate because of measurement uncertainty. Additional reaches were measured on Silver Creek, the North Fork Big Wood River, Warm Springs Creek, Trail Creek, and the East Fork Big Wood River. Discharge measurements also were made on the Hiawatha, Cove, District 45, Glendale, and Bypass Canals, and smaller tributaries to the Big Wood River and Silver Creek.

Water levels in 93 wells completed in the Wood River Valley aquifer system were measured during October 22-24, 2012; these wells are part of a network established by the U.S. Geological Survey in 2006. Maps of the October 2012 water-table altitude in the unconfined aquifer and the potentiometric-surface altitude of the confined aquifer have similar topology to those on maps of October 2006 conditions.

Between October 2006 and October 2012, watertable altitude in the unconfined aquifer rose by as much as 1.86 feet in 6 wells and declined by as much as 14.28 feet in 77 wells; average decline was 2.9 feet. A map of changes in the water-table altitude of the unconfined aquifer shows that the largest declines were in tributary canyons and in an area roughly between Baseline and Glendale Roads.

From October 2006 to October 2012, the potentiometricsurface altitude in 10 wells completed in the confined aquifer declined between 0.12 and 20.50 feet; average decline was 6.8 feet. A map of changes in the potentiometric-surface altitude of the confined aquifer shows that the largest declines were in the southwestern part of the Bellevue fan.

Reduced precipitation prior to the October 2012 water-level measurements likely is partially responsible for 2006-12 water-table declines in the unconfined aquifer; the relative contribution of precipitation deficit and groundwater withdrawals to the declines is not known. Although the confined aquifer may not receive direct recharge from precipitation or streams, groundwater withdrawal from the confined aquifer induces flow from the unconfined aquifer. Declines in the confined aquifer are likely due to groundwater withdrawals and declines in the water table of the unconfined aquifer. A statistical analysis of five long-term monitoring wells (three completed in the unconfined aquifer, one in the confined aquifer, and one outside the aquifer system boundary) showed statistically significant declining trends in four wells.

\section{Introduction}

The population of Blaine County in south-central Idaho nearly quadrupled - from about 5,700 to 22,000 peoplebetween 1970 and 2010 (Forstall, 1995; U.S. Census Bureau, 2011). In addition to permanent residents, thousands of people visit Blaine County annually for winter and summer recreation. Most population growth and recreational uses are in the northernmost part of the county in the Wood River Valley (fig. 1). The entire population of the valley depends on groundwater for its domestic water supply, either from privately owned or municipal-supply wells. Groundwater also is used for commercial, industrial, and irrigation purposes; surface water is used for recreation and irrigation. The extensive interaction between groundwater and surface water in the valley was recognized by 1921 (Chapman, 1921). 


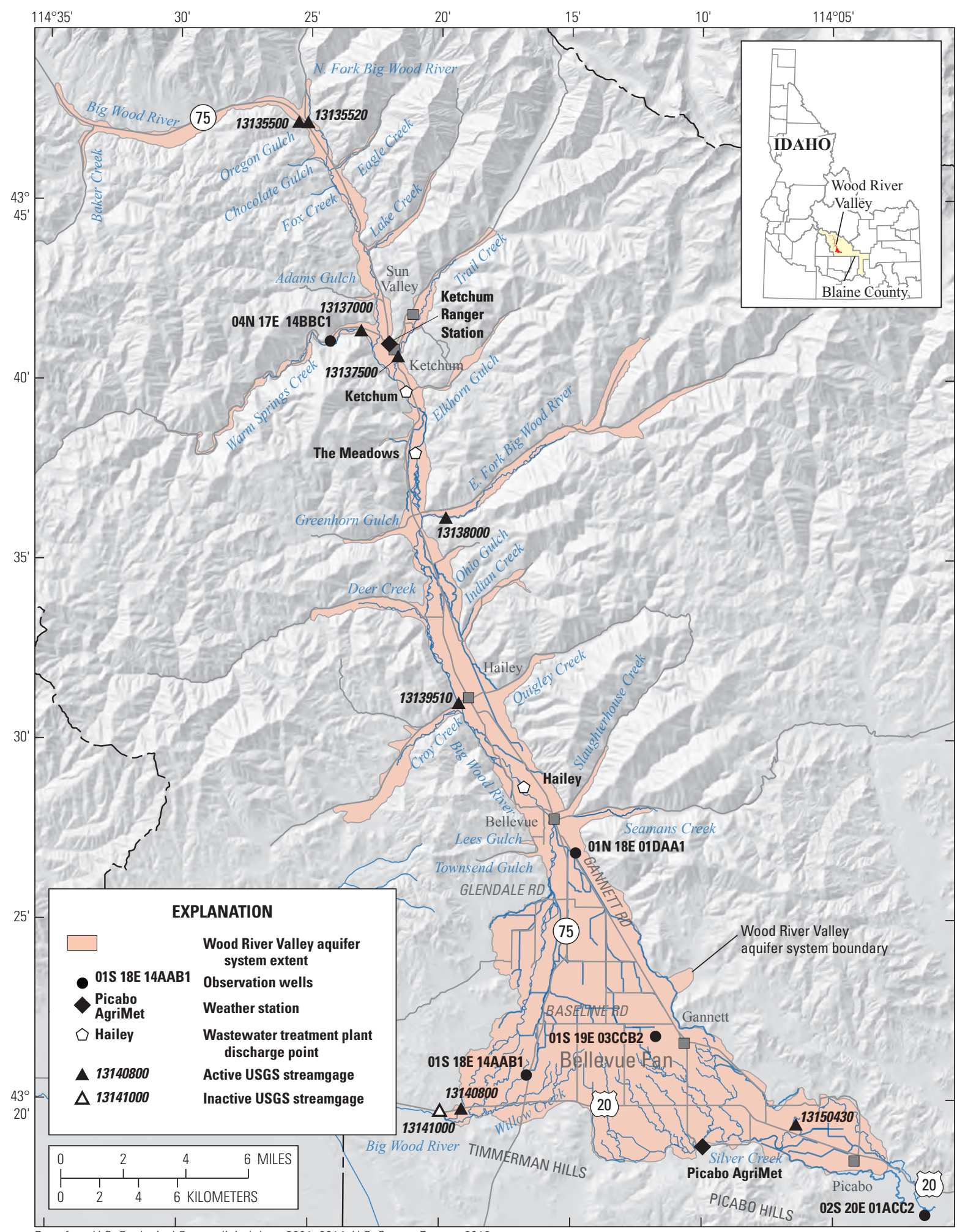

Base from U.S. Geological Survey digital data, 2001, 2014; U.S. Census Bureau, 2013;

Idaho Department of Water Resources, 1996, 1:250,000; Idaho Geospatial Data Clearinghouse, 2004;

Idaho TM, Transverse Mercator, false easting: 2,500,000.0000, false northing: 1,200,000.0000,

central meridian: -114.0000 , latitude of origin: 42.0000 , units: meter,

North American Datum of 1983.

Figure 1. Locations of communities, selected U.S. Geological Survey streamgages, weather stations, wastewater-treatment plant discharge points, and other features, Wood River Valley, south-central Idaho. 
The Idaho Department of Water Resources (IDWR) is charged with managing the water resources of the State of Idaho, and the evolution of their approach to the Wood River Valley shows the challenges associated with the coordinated management of groundwater and surface water. In 1961, concerns about the effects of groundwater withdrawals on streamflow led to the designation of the Big Wood River and Silver Creek Basins as a Critical Ground Water Area. This designation was rescinded in 1966 "at the request of local water users" (Idaho Department of Water Resources, 2014a). In 1980, the IDWR declared surface water upstream of Magic Reservoir (3.5 mi downstream and southwest of the study area) fully appropriated. The IDWR first recognized the need to plan for the conjunctive management of groundwater and surface water in 1986 (Idaho Water Resource Board, 1986). In 1991, after determining that groundwater pumping by users with junior water rights was adversely affecting surface-water diversions by users with senior water rights, the IDWR designated the Big Wood River, Silver Creek, and Camas Creek Basins as the Big Wood River Ground Water Management area (GWMA). (Camas Creek is a tributary to the Big Wood River downstream and southwest of the Wood River Valley.) The GWMA was intended to increase management of groundwater and to limit new appropriations of groundwater within the area. In 2011, the IDWR created the Upper Wood Rivers Measurement District (UWRMD) to measure and report groundwater diversions within the district boundaries. The UWRMD was abolished in 2013 when the IDWR combined Water Districts 37 and 37M and added groundwater-rights administration to the surface-water right administration duties of the district (Idaho Department of Water Resources, 2014b).

In 2012, the U.S. Geological Survey (USGS), in cooperation with the IDWR, began work on a MODFLOW numerical groundwater-flow model to advance the basic understanding of the aquifer system, and ultimately to examine effects on the groundwater system and its interaction with the Big Wood River because of changes in water use, recharge, or discharge. Groundwater-flow models have become the most commonly used tool for conjunctive administration of ground- and surface-water rights, and the model of the Wood River Valley aquifer system may also serve as a tool for water-rights administration and waterresource management and planning.

\section{Purpose and Scope}

This report describes a seepage investigation of streams and canals in the Wood River Valley and groundwater levels and water-level changes in the Wood River Valley aquifer system for inclusion in a groundwater-flow model. Streamdischarge measurements for the seepage investigation were made in August 2012, October 2012, and March 2013.
Supplemental discharge measurements made during the seepage investigation are included. Water-level measurements were made in selected wells during October 2012 and then compared to measurements made in the same wells during October 2006.

\section{Description of Study Area}

The Wood River Valley of south-central Idaho extends from Galena Summit (not shown), at the head of the Big Wood River Basin north of the study area, southward to the Timmerman and Picabo Hills (fig. 1). The valley can be separated into upper and lower parts along an east-west line immediately south of Bellevue. The upper valley is narrow, broadening downstream to a maximum width of $2 \mathrm{mi}$, and the lower valley opens into a triangular alluvial fan (the Bellevue fan) about $9 \mathrm{mi}$ across at its southern end. The study area of this report is the part of the Wood River Valley aquifer system that extends from Baker Creek southward to the Timmerman and Picabo Hills, including parts of tributary valleys with producing wells (ig. 1).

The Wood River Valley has a relatively flat bottom, and land-surface altitudes range from about $6,800 \mathrm{ft}$ at the northern boundary of the study area near the confluence of the Big Wood River with Baker Creek to about 4,800 ft at the southeastern boundary near Picabo and the southwestern boundary at Stanton Crossing (fig. 1, pl. 1). Numerous tributary canyons intersect the valley, the largest of which are those of the North Fork Big Wood River, Warm Springs Creek, Trail Creek, the East Fork Big Wood River, Deer Creek, and Croy Creek (fig. 1). The main valley and the tributary canyons have steep sides and are surrounded by highlands with peaks at altitudes of more than $11,000 \mathrm{ft}$.

In addition to their different physiographic characteristics, the upper and lower valleys also differ in land use. The upper Wood River Valley is more developed and contains the incorporated communities of Sun Valley, Ketchum, Hailey, and Bellevue. Land use in the upper valley is predominantly residential, with many large homes situated on landscaped acreage. The lower Wood River Valley is dominated by farms and ranches (irrigated by groundwater and diverted surface water), and contains the small communities of Gannett and Picabo. Although some of the tributary canyons in the upper valley, such as Trail and Warm Springs Creeks, have supported development for more than 70 years, more recent development has expanded into the other tributary canyons of the valley. Three wastewater-treatment plants in the study area discharge to the Big Wood River, another plant uses land application for treated wastewater, and many homes rely on septic systems for wastewater disposal. Other features of the study area, including climate, are described in Skinner and others (2007), Bartolino (2009), Bartolino and Adkins (2012), and Hopkins and Bartolino (2013). 


\section{Groundwater}

The Wood River Valley aquifer system is composed of a single unconfined aquifer that underlies the entire valley, an underlying confined aquifer that is present only in the southern Bellevue fan (generally to the south of Baseline Road; fig. 1), and the confining unit separating the two aquifers. The aquifer system consists primarily of Quaternary sediments of the Wood River Valley, although Quaternary basalts and interbedded sediment are the primary source of water in the southeastern Bellevue fan.

The confined aquifer is separated from the overlying unconfined aquifer by fine-grained lacustrine deposits. This confining unit thickens toward the south and, generally, as land-surface altitude decreases in the same direction, the potentiometric surface rises above land surface and some wells flow under artesian pressure. South of Gannett, near the westernmost extent of Quaternary basalt, the confining unit fingers out and the aquifer becomes solely unconfined again.

Depth to groundwater in the upper valley commonly is less than $10 \mathrm{ft}$, increasing to about $90 \mathrm{ft}$ to the south. Water levels in wells completed in the unconfined aquifer in the lower (or southern) part of the valley range from less than $10 \mathrm{ft}$ to about $150 \mathrm{ft}$. Wells completed in the confined aquifer are under artesian pressure and flow where the potentiometric surface is above land surface.

\section{Surface Water}

The Big Wood River and its tributaries drain most of the Wood River Valley; the southeastern part of the Bellevue fan is drained by Silver Creek, a tributary to the Little Wood River. The Big Wood and Little Wood Rivers meet near Gooding, about $35 \mathrm{mi}$ southwest of the study area, where they join as the Malad River, a tributary to the Snake River. The Big Wood River originates near Galena Summit, about 20 mi northwest of Ketchum, gaining flow from numerous perennial and ephemeral tributaries as it meanders across the narrow upper valley. At Bellevue, the channel follows the western side of the Bellevue fan (although flow through most of this reach is ephemeral), and exits the valley at the Big Wood River at the Stanton Crossing near Bellevue streamgage (13140800; fig. 1). Most of the streams in the tributary canyons to the Big Wood River are ephemeral and flow only in response to precipitation or snowmelt; however, the North Fork Big Wood River, Warm Springs Creek, Trail Creek, and the East Fork Big Wood River typically flow into the Big Wood River year-round. Streams in some of the smaller tributary canyons are perennial in their upper reaches, and some of this water likely infiltrates directly into the aquifer system, or reaches the Big Wood River by subsurface flow through streambed gravels. Fed by springs and seeps, Silver Creek and its tributaries originate on the
Bellevue fan; Silver Creek then flows east out of the valley at Picabo (fig. 1). A well-developed network of irrigation canals and drains is present throughout the study area; most of the Wood River Valley was under irrigation by 1900 (Jones, 1952), with the oldest water rights in the valley dating to 1880 . The diversions and return flows between the irrigation system and the Big Wood River, as well as the exchange of water between the canals, drains, and streams and the underlying unconfined aquifer, complicate the interpretation of streamflow gains and losses.

\section{Previous Work}

\section{Surface-Water Discharge and Seepage Measurements}

The first published streamflow measurements of Silver Creek and the Big Wood River were made in the summer of 1889 and are available in Powell (1891). Seepage measurements were made on the Big Wood River and Silver Creek by the U.S. Irrigation Investigation (Department of Agriculture) for the Idaho State Engineer (Ross, 1903). Chapman (1921) compiled 1921 canal deliveries for the Big and Little Wood River Basins upstream of their confluence, with additional information including descriptions of the hydrology, stream-discharge measurements from about 30 sites in the area, and seepage determinations for selected reaches.

Stearns and others (1936) assessed the groundwater resources of the Snake River Plain and its tributaries, and included a discussion of Silver Creek and the Big Wood River and their measured and estimated stream discharge near Picabo and downstream of Magic Reservoir (not shown). Jones (1952) catalogued streamgage data, reservoirs, and surface-water diversions for the entire Malad River Basin including Camas Creek and the Big and Little Wood River Basins.

Smith (1959) described the groundwater system of the Wood River Valley and noted that groundwater and surface water in the Wood River Valley "cannot be considered successfully as separate entities." Smith (1960) evaluated hydrogeologic conditions at streamgages in the Malad River Basin in order to assess the possibility of underflow and its effect on basin-yield calculations.

Castelin and Winner (1975) measured discharge at 12 sites in the Wood River Valley 6 times between September 1972 and February 1974. Moreland (1977) described groundwatersurface-water interaction in the Silver Creek area (fig. 1). As part of this investigation, Moreland measured discharge at 88 sites three times in 1975. Although unable to quantify groundwater-surface-water interaction in the Big Wood River because of the complexity introduced by diversions, Moreland demonstrated a relation between discharge in Silver Creek and water levels in shallow wells. 
Brockway and Grover (1978) measured discharge at 22 sites (streams, diversions, and returns) during the 1975 and 1976 irrigation seasons at intervals ranging from twice weekly to bi-weekly. They also made a detailed analysis of canal seepage at nine sites for application to their groundwater-flow model. Luttrell and Brockway (1984) measured discharge at 13 sites on the Big Wood River and tributaries in September 1983 and March 1984 to determine streamflow gain or loss on the Big Wood River.

Frenzel (1989) conducted a seepage study in August 1986 with discharge measurements at 22 sites including the Big Wood River, various tributaries, and canal diversions. Frenzel's report included a qualitative comparison of water levels in four wells near the Big Wood River and various canals to discharge in the Big Wood River.

Brockway and Kahlown (1994) installed stage recorders or staff gages at 15 sites on the Bellevue fan; the stage was read on a weekly basis between May 1993 and April 1994. An additional three sites on the District 45 canal were instrumented and read on a weekly basis during the 1993 irrigation season.

Skinner and others (2007) analyzed historic trends in streamflow at three streamgages: Big Wood River at Hailey (13139510, B05), Big Wood River near Bellevue (13141000, B12), and Silver Creek at Sportsman Access (13150430, S01) (figs. 1 and 2). The report describes 13 discharge measurements made in October 2006 for the determination of streamflow gains and losses and contains a table of streamgages within a 25-mi radius of the Wood River Valley and the period of record for each.

Personnel at the Nature Conservancy Silver Creek Preserve have collected streamflow and water temperature data for Silver Creek and its tributaries. Much of these data are available from Save Silver Creek (2014).

\section{Water-Level Measurements}

Chapman (1921) created the earliest groundwater-level map of the Wood River Valley, which shows conditions in the Bellevue fan area south of Bellevue (fig. 1) during June 1921. A report by Stearns and others (1936) contains a smallscale groundwater-level map of conditions during 1928-30 in the eastern Snake River Plain and selected tributaries including the Bellevue fan area and the Camas Prairie. Smith (1959), Castelin and Chapman (1972), Moreland (1977), Brockway and Grover (1978), Luttrell and Brockway (1984), Frenzel (1989), Wetzstein and others (2000), and Skinner and others (2007) prepared subsequent groundwater-level maps of all or parts of the Wood River Valley. Small-scale groundwater-level maps that include the Wood River Valley include those by Mundorff and others (1964), Maupin (1991, 1992), Berenbrock and others (1995), and Briar and others (1996).

\section{Methods}

\section{Surface-Water Discharge Measurement and Uncertainty}

Stream-discharge measurements were made in accordance with USGS methods (Rantz and others, 1982; Rantz, 1982; Oberg and others, 2005; Mueller and Wagner, 2009; Turnipseed and Sauer, 2010; Wood, M.S., and Evetts. D.M., written commun., 2014). Measurements were made with either a SonTek FlowTracker ${ }^{\circledR}$ handheld acoustic Doppler velocimeter (ADV) or conventional vertical-axis current meter.

Measurement uncertainty for both types of instruments is expressed as a percentage of the measured total stream discharge. The FlowTracker ${ }^{\circledR}$ ADV calculates these uncertainties within the instrument using statistical techniques developed by the USGS; the uncertainties are described in SonTek/YSI (2009). Measurements made with a conventional current meter are assigned a rating of excellent, good, fair, or poor by the hydrographer with associated measurement errors of $\pm 2, \pm 5, \pm 8$, or more than \pm 8 percent, respectively (Turnipseed and Sauer, 2010). In this report, measured streamdischarge values are shown with uncertainty expressed as plus or minus cubic feet per second $\left( \pm \mathrm{ft}^{3} / \mathrm{s}\right)$.

\section{Determination of Seepage and Uncertainty}

A seepage run is performed in order to determine the movement of water between surface water and the underlying groundwater. This flux is determined by measuring stream discharge at the upstream and downstream ends of a reach and then accounting for surface-water inflows or diversions within the reach. If discharge has increased throughout the reach, the additional flow may be attributed to groundwater discharge into the stream (streamflow gain). If stream discharge has decreased throughout the reach, the lost flow can be presumed to have infiltrated to groundwater as recharge (streamflow loss).

Because two or more discharge measurements are needed to determine streamflow gain or loss, the uncertainty associated with each discharge measurement propagates through the seepage calculation. This uncertainty can be quantified by the application of the error propagation formula. The resulting uncertainty estimate thus incorporates the uncertainty of each discharge measurement used in the seepage calculation (Wheeler and Eddy-Miller, 2005). A limitation of this gain-loss estimation method is that the collective uncertainty of all discharge measurements used to estimate streamflow gain or loss in a given reach can exceed the estimated gain or loss. In such cases, confidence in the actual value of the estimated gain or loss is diminished. 
Seepage in individual subreaches may differ from that of the entire reach. As a result, the location of discharge measurement sites that define a particular reach may affect the determination of seepage; shifting the reach slightly can affect the calculated value or direction of seepage.

Stream-discharge values are shown as recorded by the hydrographer who made the measurement and correspond to the values in the USGS National Water Information System (U.S. Geological Survey, 2014a). Seepage estimates are reported to the appropriate number of significant figures using standard procedures (Hansen, 1991). Numbers that require rounding with a last digit of 5 are rounded to the nearest even number.

\section{Groundwater-Level Measurement}

Water levels were measured in 93 wells completed in the Wood River Valley aquifer system during October 22-24, 2012, in accordance with USGS methods (Cunningham and Schalk, 2011). In non-flowing wells, water levels were measured using either steel tapes or calibrated electric tapes. In flowing wells, water levels were measured with a calibrated digital pressure gage. Ten of the 93 wells were completed in the confined aquifer; the remaining wells were completed in the unconfined aquifer (some wells also were completed into consolidated bedrock). These wells were part of the 98-well groundwater-level network established and measured by the USGS during October 23-27, 2006 (Skinner and others, 2007). Five of the wells measured in 2006 were not measured in 2012, typically because permission was not granted.

\section{Water-Level and 2006-12 Change Maps}

The October 2012 groundwater-level maps and 2006-12 groundwater-level change maps were produced with the $\operatorname{ArcMap}^{\mathrm{TM}} 10.1$ geographic information system (GIS) (Environmental Systems Research Institute, 2014). Water levels measured in October 2012 were used to create water-table and potentiometric-surface maps of the unconfined and confined aquifers, respectively. Water levels measured in October 2012 were subtracted from water levels measured in October 2006 for each well measured during 2012 to create water-table and potentiometric-surface change maps of the unconfined and confined aquifers, respectively. The maps were created by evaluating water-level data in $\operatorname{ArcMap}^{\mathrm{TM}}$ using the "Spline with Barriers" interpolation tool to create a raster surface for each of the four maps. Contour lines representing water-level altitude and waterlevel change then were drawn from the raster surface to create the final maps. Contour lines that were artifacts of the interpolation tool were eliminated and contour lines in areas of uncertainty were dashed.
The groundwater-level network established in 2006 does not contain any wells completed in the unconfined aquifer in the far southwestern area of the aquifer system. In order to extend contours into this area, it was assumed that $0.0 \mathrm{ft}$ stage at the Big Wood River at Stanton Crossing near Bellevue streamgage (13140800) (fig. 1; marked as well SC on plates 1 and 3) represented the water table with an altitude of $4,828 \mathrm{ft}$ (Bartolino and Adkins, 2012). This is a reasonable assumption because much of the land in the southern Bellevue fan is wetland or has a shallow water table.

In this report, a one- or two-digit number is used to identify wells completed in the unconfined aquifer; a $\mathrm{C}$ is added if the well is completed in the confined aquifer (pls. 1, 2, and 3; appendix table B1). The one- or two-digit numbers are the same numbers used by Skinner and others (2007, appendix A), October 2006 water-table and potentiometricsurface maps. Because Skinner and others (2007) used separate numbering systems for the two aquifers, the $\mathrm{C}$ was added to avoid duplication of numbers. The full USGS site identification number is listed in table B1.

\section{Groundwater-Level Trend Analysis}

Water levels in four wells completed in the Wood River Valley aquifer system and one well completed in similar rocks adjacent to the study area were evaluated with the nonparametric seasonal Kendall (for two and four seasons) and Mann-Kendall tests to determine the presence of any statistically significant trends in water levels. If the Kendall's S statistic is significantly different from zero, it may be concluded that there is a monotonic trend in water levels over time. Temporal trends in groundwater levels were considered to be statistically significant if the p-value (or level of significance) was less than 0.005 at a confidence level of 99.5 percent. A detailed discussion of these techniques is given in Helsel and Hirsch (1992). Statistical tests were made with free USGS R-language statistical packages (U.S. Geological Survey, 2014b).

\section{Stream Seepage}

Stream-discharge measurements for determination of seepage were made during several days on three occasions: August 27-28, 2012, October 22-24, 2012, and March 27-28, 2013. Discharge measurements were made at 49 sites in August and October 2012, and 51 sites in March 2013. The locations of the measurement sites on the Big Wood River, Silver Creek, their tributaries, and canals are shown in figure 2. The names, locations, and measurement conditions for the sites are listed in table 1. Summaries of the discharge measurements and measured gain or loss for the three seepage runs are in tables $\mathrm{A} 1, \underline{\mathrm{A} 2}$, and $\underline{\mathrm{A}} 3$. 


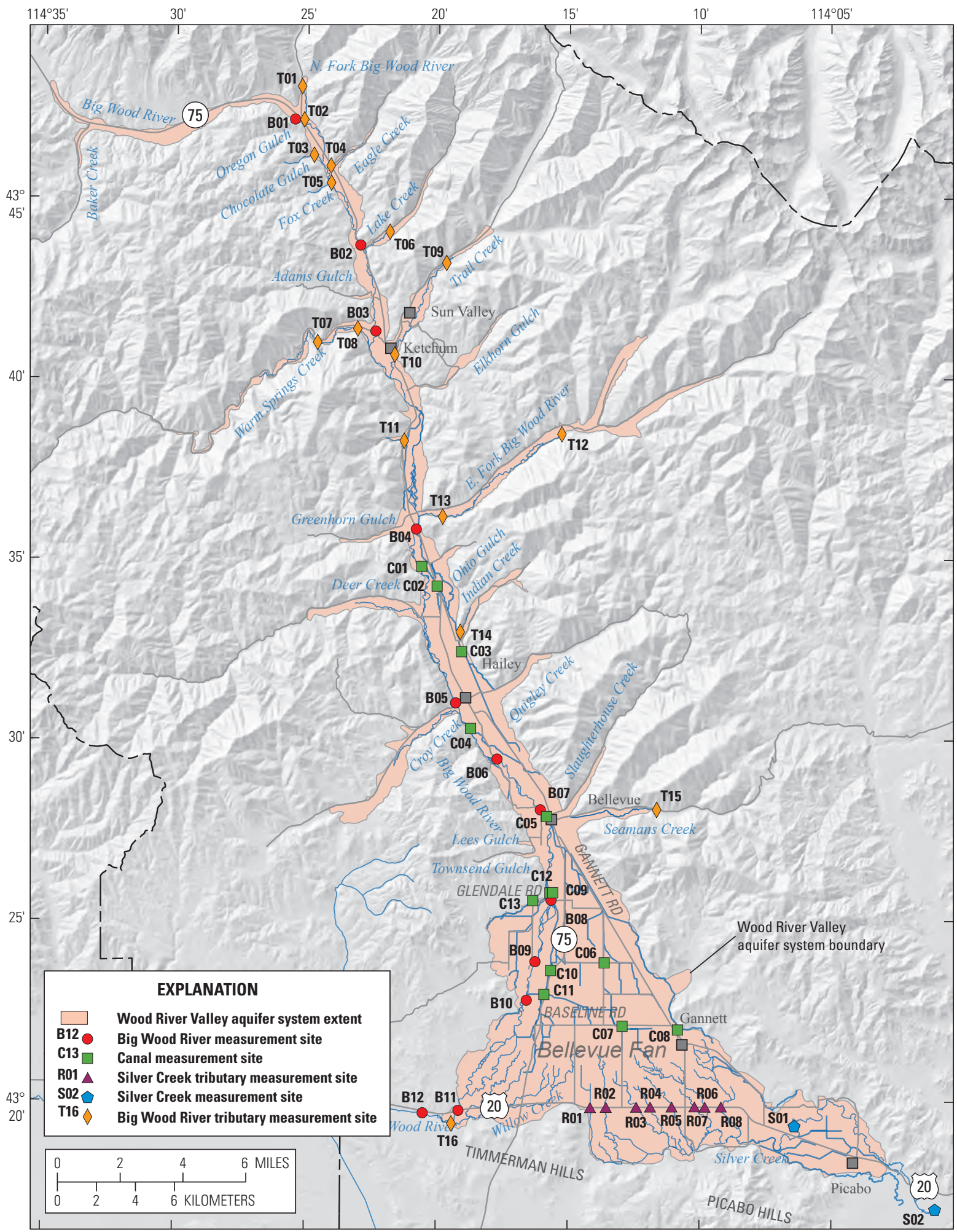

Base from U.S. Geological Survey digital data, 2001, 2014; U.S. Census Bureau, 2013;

Idaho Department of Water Resources, 1996, 1:250,000; Idaho Geospatial Data Clearinghouse, 2004

Idaho TM, Transverse Mercator, false easting: 2,500,000.0000, false northing: 1,200,000.0000,

central meridian: -114.0000 , latitude of origin: 42.0000 , units: meter,

North American Datum of 1983

Figure 2. Stream-discharge measurement sites, Wood River Valley, south-central Idaho, August and October 2012, and March 2013. 
Table 1. Stream discharge measurement sites and measurement conditions, Wood River Valley, south-central Idaho, August 2012, October 2012, and March 2013.

[Locations of sites shown in figure 2. Measurement condition: $\bullet$, flow measured; $\circ$, no flow present; -, site inaccessible. Abbreviations: NAD 83, North American Datum of 1983; ID, Idaho; Rd., Road; NRA, National Recreation Area]

\begin{tabular}{|c|c|c|c|c|c|c|c|}
\hline \multirow[b]{2}{*}{$\begin{array}{l}\text { Site } \\
\text { No. }\end{array}$} & \multirow[b]{2}{*}{ Site name } & \multirow{2}{*}{$\begin{array}{l}\text { Site } \\
\text { identification } \\
\text { No. }\end{array}$} & \multirow{2}{*}{$\begin{array}{l}\text { Latitude } \\
\text { (NAD 83) } \\
\text { (decimal } \\
\text { degrees) }\end{array}$} & \multirow{2}{*}{$\begin{array}{l}\text { Longitude } \\
\text { (NAD 83) } \\
\text { (decimal } \\
\text { degrees) }\end{array}$} & \multicolumn{3}{|c|}{ Measurement condition } \\
\hline & & & & & $\begin{array}{l}\text { August } \\
2012\end{array}$ & $\begin{array}{c}\text { October } \\
2012\end{array}$ & $\begin{array}{c}\text { March } \\
2013\end{array}$ \\
\hline B01 & Big Wood River near Ketchum, ID & 13135500 & 43.7863 & -114.4251 & $\bullet$ & $\bullet$ & $\bullet$ \\
\hline B02 & Big Wood River at Sage Rd. Bridge near Ketchum, ID & 13135840 & 43.7283 & -114.3831 & - & $\bullet$ & $\bullet$ \\
\hline B03 & Big Wood River at Ketchum, ID & 13136000 & 43.6887 & -114.3733 & $\bullet$ & $\bullet$ & $\bullet$ \\
\hline B04 & Big Wood River at Gimlet, ID & 13138500 & 43.5974 & -114.3470 & $\bullet$ & $\bullet$ & $\bullet$ \\
\hline B05 & Big Wood River at Hailey, ID total flow & 13139510 & 43.5974 & -114.3470 & $\bullet$ & $\bullet$ & $\bullet$ \\
\hline B06 & Big Wood River below North Broadford Bridge near Hailey, ID & 432929114174300 & 43.5974 & -114.3470 & $\bullet$ & $\bullet$ & $\bullet$ \\
\hline B07 & Big Wood River at South Broadford Bridge near Bellevue, ID & 432805114160400 & 43.5974 & -114.3470 & $\bullet$ & $\bullet$ & $\bullet$ \\
\hline B08 & Big Wood River at Glendale Bridge near Bellevue, ID & 13140500 & 43.5974 & -114.3470 & $\bullet$ & $\bullet$ & $\bullet$ \\
\hline B09 & Big Wood River at Sluder Drive near Bellevue, ID & 432352114161500 & 43.5974 & -114.3470 & - & - & $\bullet$ \\
\hline B10 & Big Wood River at Wood River Ranch near Bellevue, ID & 432248114163400 & 43.5974 & -114.3470 & - & - & $\bullet$ \\
\hline B11 & Big Wood River at Stanton Crossing near Bellevue, ID & 13140800 & 43.3292 & -114.3192 & $\bullet$ & $\bullet$ & $\bullet$ \\
\hline B12 & Big Wood River near Bellevue, ID & 13141000 & 43.3280 & -114.3418 & $\bullet$ & $\bullet$ & $\bullet$ \\
\hline $\mathrm{C} 01$ & Hiawatha Canal at point of diverson near Gimlet, ID & 13138600 & 43.5801 & -114.3435 & $\bullet$ & $\bullet$ & $\circ$ \\
\hline $\mathrm{C} 02$ & Hiawatha Canal at ID Highway 75 near Hailey, ID & 433416114200100 & 43.5711 & -114.3336 & $\bullet$ & $\bullet$ & ० \\
\hline $\mathrm{C} 03$ & Hiawatha Canal at Red Devil Road near Hailey, ID & 433227114190500 & 43.5408 & -114.3180 & $\bullet$ & $\bullet$ & $\circ$ \\
\hline $\mathrm{C} 04$ & Cove Canal at point of diverson near Hailey, ID & 433020114184400 & 43.5054 & -114.3121 & $\bullet$ & $\bullet$ & ○ \\
\hline $\mathrm{C} 05$ & District 45 Canal at diverson near Bellevue, ID & 432754114155000 & 43.4649 & -114.2638 & $\bullet$ & $\bullet$ & $\circ$ \\
\hline C06 & District 45 Canal at Pero Road near Gannett, ID & 432351114133700 & 43.3975 & -114.2270 & $\bullet$ & $\circ$ & ○ \\
\hline $\mathrm{C} 07$ & District 45 Canal at Price Lane near Bellevue, ID & 432258114125600 & 43.3682 & -114.2156 & $\circ$ & $\bullet$ & $\circ$ \\
\hline C08 & District 45 Canal at Loving Creek near Gannett, ID & 432200114105000 & 43.3666 & -114.1805 & $\bullet$ & $\bullet$ & ० \\
\hline C09 & Bypass Canal at point of diversion near Bellevue & 13140495 & 43.4297 & -114.2615 & $\bullet$ & $\bullet$ & $\bullet$ \\
\hline $\mathrm{C} 10$ & Bypass Canal at Alpine Kennels near Bellevue, ID & 432338114153900 & 43.3938 & -114.2609 & $\bullet$ & $\bullet$ & $\circ$ \\
\hline C11a & $\begin{array}{l}\text { Bypass Canal above and below diversion near Bellevue, ID } \\
\text { (above Baseline extension/return to Big Wood River junction) }\end{array}$ & 13140600 & 43.3828 & -114.2651 & $\bullet$ & $\bullet$ & $\circ$ \\
\hline $\mathrm{C} 11 \mathrm{~b}$ & $\begin{array}{l}\text { Bypass Canal above and below diversion near Bellevue, } \\
\text { ID (return to Big Wood River) }\end{array}$ & 13140600 & 43.3828 & -114.2651 & $\circ$ & $\bullet$ & $\circ$ \\
\hline $\mathrm{C} 12$ & $\begin{array}{l}\text { Glendale Canal at point of diverson } \\
\text { near Bellevue, ID }\end{array}$ & 432547114153500 & 43.4298 & -114.2597 & $\bullet$ & $\bullet$ & $\circ$ \\
\hline $\mathrm{C} 13$ & Glendale Canal at Glendale Road near Bellevue, ID & 432534114162000 & 43.4261 & -114.2723 & $\circ$ & $\circ$ & $\circ$ \\
\hline
\end{tabular}


Table 1. Stream discharge measurement sites and measurement conditions, Wood River Valley, south-central Idaho, August 2012, October 2012, and March 2013.-Continued

[Locations of sites shown in figure 2. Measurement condition: • flow measured; $\circ$, no flow present; -, site inaccessible. Abbreviations: NAD 83, North American Datum of 1983; ID, Idaho; Rd., Road; NRA, National Recreation Area]

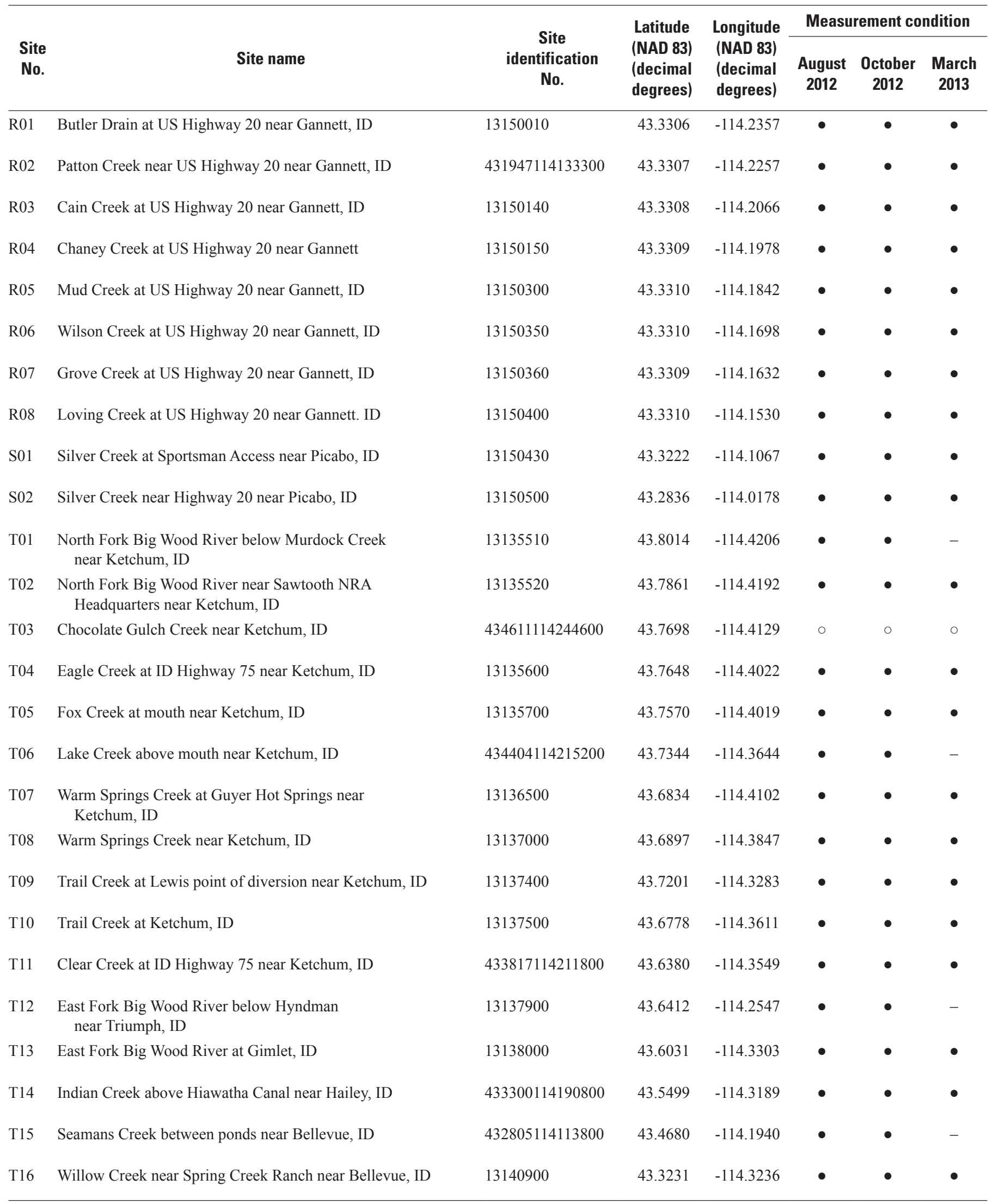




\section{Big Wood River}

Stream discharge was measured at 10 sites on the Big Wood River in August and October 2012, and at 12 sites in March 2013 (sites B09 and B10 were not visited in August and October) (fig. 2; table 1). Discharge measurements were supplemented with measurements of tributary inflow and canal diversions at 16 sites to determine streamflow gain or loss in 9 reaches (11 reaches in March 2013) of the Big Wood River (igs. 2 and $\underline{3}$; tables $1, \underline{\mathrm{A} 1}, \underline{\mathrm{A} 2}$, and $\underline{\mathrm{A} 3}$ ).

The reach between the Big Wood River near Ketchum streamgage (13135500, B01) and the Sage Road Bridge site (B02) gained flow during all three measurements. Three small tributary canyons and one large tributary canyon, the North Fork Big Wood River, contribute subsurface inflow to the aquifer. Although most homes in the B01-B02 reach have wells, housing density along this reach is relatively sparse compared to the remainder of the Wood River Valley.

The Sage Road Bridge (B02) to Ketchum (B03) reach seemed to lose flow during all measurements; however, uncertainty was greater than the measured loss in March and October. The measured loss in this reach may be caused by a combination of: (1) increased development density down valley toward Ketchum (many homes in the area have domestic wells), (2) only two tributaries seem to contribute subsurface inflow, and (3) large uncertainty is present in the discharge and seepage measurements.

Seepage in the two reaches from Ketchum (B03) to the Big Wood River at Hailey streamgage (13139510, B05) varied seasonally. In August, uncertainty was greater than the small measured gain in the B03-B04 reach and there was no gain or loss in the B04-B05 reach. In October, both reaches seemed to gain flow; however, in the B04-B05 reach, uncertainty was greater than the measured gain. In March, both reaches gained flow. Although development is relatively dense in these two reaches with numerous individual and community wells, the presence of several large and numerous small tributary canyons may contribute a greater volume of subsurface inflow than the B02-B03 reach.

The three reaches between the Big Wood River at Hailey streamgage (13139510, B05) and the Glendale Bridge site (B08) were determined to be losing reaches during all three measurements. Possible reasons for these losses include: (1) precipitation decreases down valley; (2) few tributary canyons contribute subsurface inflow; and (3) depth to groundwater increases away from the channel, thereby inducing flow from the Big Wood River.

The Glendale Bridge (B08) site to the Big Wood River at Stanton Crossing near Bellevue streamgage (13140800, B11) reach was a gaining reach in August 2012 but a losing reach in October 2012 and March 2013 (fig. 3). The March seepage measurements included two additional sites: Big Wood River at Sluder Drive near Bellevue (B09) and Big Wood River at Wood River Ranch near
Bellevue (B10) - both reaches lost flow. The measured gain in the B08-B11 reach during August is not representative of the entire reach. During the late summer and early autumn, nearly all the flow of the Big Wood River is diverted into the Baseline Bypass Canal at site C09 (fig. 2). The Bypass Canal was built in 1920 to route water around the "Dry Bed" section of the Big Wood River to speed the passage of water through this section of the river and to reduce losses (Chapman, 1921). At site C11, flow can be routed south to the Baseline Bypass extension canal or west back to the braided channel of the Big Wood River in the lower part of the B09-B10 reach. The B10-B11 reach contains a series of springs that (in combination with streamflow from several spring-fed tributaries) supply the base flow at the Big Wood River at Stanton Crossing near Bellevue streamgage (13140800, B11). When the entire flow of the river is diverted upstream of the Glendale Bridge (B08) and there is no return flow from the Bypass, all the flow at site B11 enters the river in the B10-B11 reach. Therefore, during the August seepage measurements, the measured gain of $26 \mathrm{ft}^{3} / \mathrm{s}$ represents base flow at the Big Wood River at Stanton Crossing near Bellevue streamgage (13140800, B11). This value is similar to mean discharge at this streamgage for December-February (which represents base flow) of $34 \mathrm{ft}^{3} / \mathrm{s}$. However, at larger flows, such as from Bypass return flow (October) or when the entire B08-B10 reach is flowing (March), the B10-B11 reach loses flow. As with the B05-B08 reach, these losses may be caused by decreased precipitation down valley, fewer tributary canyons to contribute subsurface inflow, and increased depth to groundwater away from the channel of the Big Wood River.

Finally, the reach between the Big Wood River at Stanton Crossing near Bellevue streamgage (13140800, B11) and the Big Wood River near Bellevue site (B12) lost flow in August and gained flow in October (although uncertainty was equal to measured seepage) and March. Discharge at sites B11, B12, and Willow Creek (T16) were similar in August and October, and no diversions or wells are in this reach. It is not clear what changed between August and October to reverse seepage direction.

Direct comparison of seepage measurements in this report with previous work is difficult because measurements have been made during different months, at different sites, and with different methodologies, and some tributaries or diversions may have been neglected. Previous measurements also have not included estimates of uncertainty. The gain measured in the reach between the Big Wood River near Ketchum streamgage (13135500, B01) and the Big Wood River at Hailey streamgage total flow (13139510, B05) generally agrees with all previous seepage determinations. As in this report, previous work determined that the reaches between the Big Wood River at Hailey streamgage (13139510, B05) and the Big Wood River at Stanton Crossing near Bellevue streamgage (13140800, B11) both gained and lost flow, primarily because of the Baseline Bypass. 
August 27-28, 2012

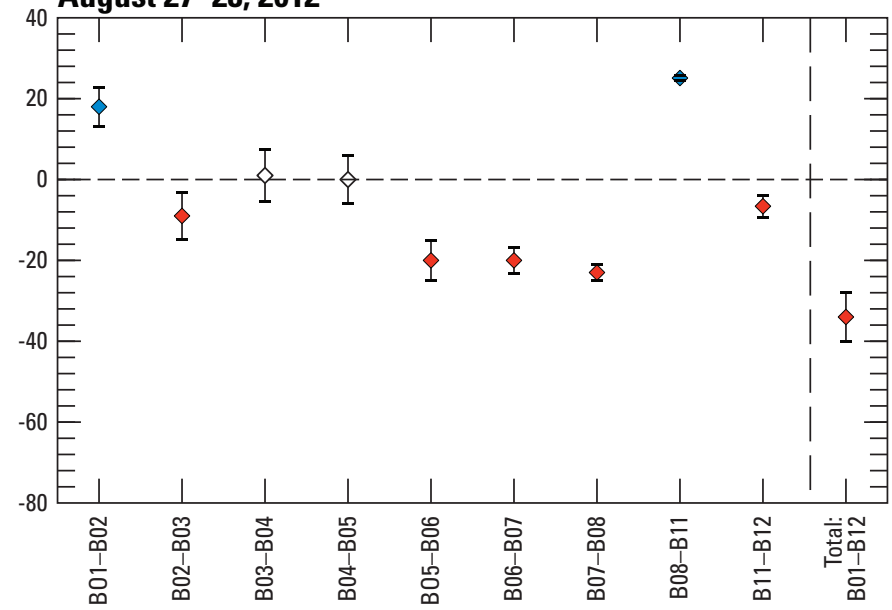

EXPLANATION

$\checkmark$ Gaining reach

- Losing reach

$\triangle$ Uncertainty greater than measurement

Upper bound of

uncertainty

-Measured gain

(+) or loss (-)

Lower bound of

uncertainty
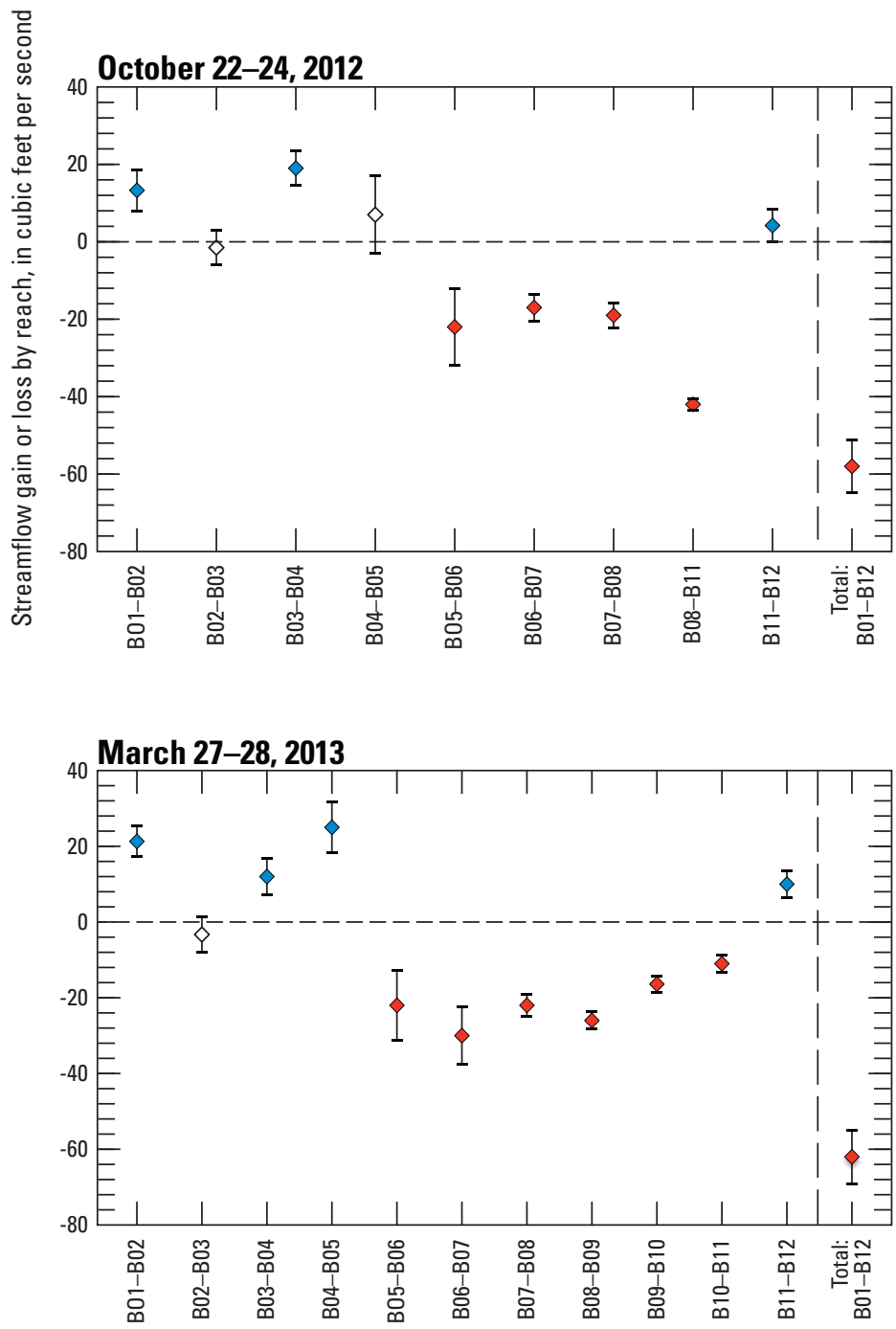

Big Wood River reach

Figure 3. Measured streamflow gain or loss by reach, Big Wood River, Wood River Valley, south-central Idaho, 2012-13. Discharge measurement locations are shown in figure 2 and table 1. 


\section{Wastewater Treatment Plant Discharge}

Three wastewater-treatment plants (WWTPs) discharge to the Big Wood River: the City of Ketchum (which includes Sun Valley Water and Sewer District wastewater), The Meadows recreational vehicle park, and the City of Hailey (fig. 1). (The fourth WWTP, the City of Bellevue, uses land application.) WWTP discharge data are available on the U.S. Environmental Protection Agency (EPA) Enforcement and Compliance History Online Web site (U.S. Environmental Protection Agency, 2013). These data vary in quality, accuracy, and period of record.

The Ketchum WWTP discharges in the reach between sites B03 and B04 (figs. 1 and 2) - mean discharge (January 1995-December 2010) is $2.4 \mathrm{ft}^{3} / \mathrm{s}$. The Meadows WWTP (fig. 1) discharges in the same reach-mean discharge (February 2000-December 2010) is $0.50 \mathrm{ft}^{3} / \mathrm{s}$. The Hailey WWTP (fig. 1) discharges in the reach between sites B07 and B08 (fig. 2) - mean discharge (June 1996-December 2010) is $0.77 \mathrm{ft}^{3} / \mathrm{s}$.

Discharge from the three WWTPs that discharge to the Big Wood River was not considered in calculating streamflow gains and losses for two reasons. First, discharge data on the EPA site are given as a monthly mean daily flow; therefore, determination of instantaneous discharge during the seepage measurements is not possible. Second, all reported WWTP discharges were less than the measurement uncertainty for the calculated gain or loss in the affected reaches.

\section{Big Wood River Tributaries}

Seepage was determined on four tributary streams to the Big Wood River: the North Fork Big Wood River, Warm Springs Creek, Trail Creek, and the East Fork Big Wood River (figs. 1 and 2; tables 1, $\underline{\mathrm{A} 1}, \underline{\mathrm{A} 2}$, and $\underline{\mathrm{A} 3}$ ). Two discharge-measurement sites were established on each stream, and all eight sites were measured in August and October 2012. In March 2013, the upper sites on the North Fork Big Wood River and the East Fork Big Wood River were inaccessible because of snow; therefore, March seepage was not determined for these two tributaries.

The North Fork Big Wood River reach (T01-T02) appeared to lose flow in August and October, but uncertainty exceeded the seepage value, thus making the measurements indeterminate (tables A1 and A2). The Warm Springs Creek reach (T07-T08) had little or no measurable streamflow gain or loss during all three seepage runs, and all were indeterminate because measurement uncertainty exceeded the rather slight measured seepage (tables A1, $\underline{\mathrm{A} 2}$, and $\underline{\mathrm{A} 3}$ ). The Trail Creek reach (T09-T10) lost flow during all three seepage measurements. The East Fork Big Wood River reach (T12-T13) lost flow in August and October (tables A1 and $\underline{\mathrm{A} 2})$.

\section{Silver Creek and Tributaries}

Stream-discharge measurements were made at two sites on Silver Creek (S01 and S02) during August 2012, October 2012, and March 2013 (fig. 2; tables 1, A1, A2, and A3). The downstream measurement was made at the site of a USGS streamgage that operated during 1920-62. Although part of this reach lies outside the boundary of the Wood River Valley aquifer system (fig. 1), hydrologic conditions there are similar to those within the aquifer boundary; therefore, this reach may be considered representative of hydrologic conditions within the boundary. In August, the Silver Creek reach (S01-S02) gained flow (table A1). It should be noted that the diversion data used in the gain-loss estimate for this reach were not measured as part of this investigation. The diversion data were provided by the local Water District 37 (Kevin Lakey, Watermaster, Water District 37, written commun., March 24, 2014); therefore, uncertainty values could not be assigned to the diversion data. No diversions were reported during October and March. In October, the Silver Creek reach gained flow, although measurement uncertainty was nearly as large as the calculated gain. In March, there was no measured loss or gain, but measurement uncertainty was $5.3 \mathrm{ft}^{3} / \mathrm{s}$.

In addition to the measurement sites on Silver Creek, stream discharge was measured at eight sites on tributaries to Silver Creek where they cross U.S. Highway 20 (fig. 2; tables $1, \underline{A} 1, \underline{A}$, and $\underline{\mathrm{A} 3}$ ). All these tributaries enter Silver Creek upstream of the Silver Creek at Sportsman Access near Picabo streamgage (13150430, S01) (figs. 1 and 2; table 1) and, therefore, do not affect the measured seepage for the reach downstream of this streamgage. All the measured tributaries originate as seeps and springs.

\section{Canals}

Discharge measurements were made on four canals that divert water from the Big Wood River in the Wood River Valley (igg. 2; tables 1, $\underline{\mathrm{A} 1}, \underline{\mathrm{A} 2}$, and $\underline{\mathrm{A} 3}$ ). These canals are mostly unlined, but they contain some concrete-lined sections. When flow was present, all canals lost flow between the measurement sites, although measured seepage was indeterminate on several canals because of unmeasured diversions and returns. Because numerous small diversions and returns with flow rates of several cubic feet per second occur between the discharge-measurement sites, the August seepage determinations for canals have additional uncertainty. Although discharge measurements were made, seepage was not determined on the District 45 canal (sites C05-C08; fig. 2; tables $1, \underline{\mathrm{A} 1}, \underline{\mathrm{A} 2}$, and $\underline{\mathrm{A} 3}$ ) because of diversions and intersections with other canals. Water District 37-37M records do not report any small diversions during the October and March measurements. 


\section{Water Levels In October 2012 and Change From October 2006}

Water levels in 93 wells in the Wood River Valley study area were measured during October 22-24, 2012 (table B1; pls. 1, 2, and 3). These wells are part of the groundwater-level network established in 2006 and described in Skinner and others (2007).

\section{Conditions in October 2012}

\section{Unconfined Aquifer}

Water levels were measured in 83 wells completed in the unconfined aquifer (including wells with additional screened intervals into underlying bedrock) during October 22-24, 2012 (table B1; pl. 1). Plate 1 shows the configuration of the water table compiled from these measurements using 25 - $\mathrm{ft}$ contours (or as otherwise labeled). The water table has a fairly uniform gradient that generally mimics the land surface decreasing down the valley and tributary canyons to the Bellevue fan. Near Baseline Road, a roughly north-south divide occurs in the water-table surface; the water table then slopes southwest to the Big Wood River at Stanton Crossing near Bellevue streamgage (13140800, B11) and southeast to Picabo. The contours of the October 2012 water table have the same general topology as shown in the October 2006 water table in Skinner and others (2007).

In addition to adding the water surface at the Big Wood River at Stanton Crossing near Bellevue streamgage (13140800, B11) as a water-table elevation (as described in section, "Methods"), a well in Elkhorn Gulch measured in October 2006 but not included in Skinner and others (2007) was included on the 2012 unconfined aquifer maps in the current report (well 88, table B1; pls. 1 and 3). This well, and others completed in tributary canyons, is screened across both the unconfined aquifer and the underlying bedrock aquifers. Although such completions can be for wellbore storage of water in areas of low-yielding wells, drillers' logs for these wells show water-producing zones in the bedrock. Therefore, the water level in these wells may represent a combination of water levels in the bedrock and unconfined aquifer.

\section{Confined Aquifer}

The potentiometric-surface map of the confined aquifer was constructed with water levels measured in 10 wells during October 22-23, 2012, and uses 10-ft contour intervals (pl. 2A). The potentiometric surface is highest near the intersection of Baseline Road and Idaho Highway 75 (pl. 2A), and slopes to the southwest where the Big Wood River leaves the valley at the Big Wood River at Stanton Crossing near Bellevue streamgage (13140800, B11), and to the southeast where the confined aquifer merges with the unconfined aquifer and water levels become unconfined. The contours of the October 2012 potentiometric surface have the same general shape as the contours of the October 2006 potentiometric surface shown in Skinner and others (2007).

\section{Change During October 2006-0ctober 2012}

The groundwater-level change maps presented in this report are based on comparisons of water levels measured in the same wells during October 2006 and October 2012 (pls. 2B and 3). These maps may be considered more reliable representations of water-level change than the partial development to October 2006 change maps shown in Skinner and others (2007) that compared interpolated surfaces rather than individual wells. Because the 2006 and 2012 measurements were both made in late October, the effect of seasonal variation in water levels noted by previous investigations also is minimized.

\section{Unconfined Aquifer}

Water levels from the same 83 wells used to construct the October 2012 water-table map were compared to water levels measured during October 23-26, 2006, to produce a water-level change map with 2-ft contours (table B1; pl. 3 ). Water levels rose between 2006 and 2012 in six wells; the maximum increase was $1.86 \mathrm{ft}$ (well 3). Water levels in the remaining 77 wells declined by as much as $14.28 \mathrm{ft}$ (well 36); the average decline was $2.9 \mathrm{ft}$. The largest declines were in tributary canyons and an area roughly between Baseline and Glendale Roads (fig. 1, pl. 3).

\section{Confined Aquifer}

The water levels measured in the same 10 wells used to construct the October 2012 potentiometric-surface map (pl. 2B) were compared to water levels measured in the same wells during October 23-26, 2006. Water levels in all measured wells declined between 2006 and 2012; changes in the altitude of potentiometric surface with 2-ft contour intervals are shown in plate $2 B$. The southwestern part of the Bellevue fan near the Big Wood River at Stanton Crossing near Bellevue streamgage (13140800, B11) (fig. 1) showed the greatest decline in the potentiometric surface of $20.50 \mathrm{ft}$ (well C40) (table B1; pl. 2B). The smallest decline of $0.12 \mathrm{ft}$ (well C45) (table B1; pl. 2B) was in the southeastern part of the Bellevue fan near Picabo (fig. 1); the average decline was $6.8 \mathrm{ft}$. 


\section{Probable Causes of Water-Level Declines}

There are three main probable causes for the water-level declines described in this report: changes in precipitation over the aquifer system during the period leading up to the October 2006 and 2012 measurements, groundwater pumping, and decreased surface-water supply.

Precipitation during the 12 months preceding the 2012 water-level measurements was compared to precipitation during the 12 months prior to the 2006 water-level measurements at the Picabo AgriMet and Ketchum Ranger Station weather stations (fig. 1). At the Picabo AgriMet station, precipitation was near normal during water years (October 1-September 30) 2005 and 2011. Average annual precipitation was 18.0 in. at the Ketchum Ranger Station weather station (1981-2010) and 12.4 in. at the Picabo AgriMet station (1983-2013) (Bureau of Reclamation, 2014; National Climatic Data Center, 2014; Western Regional Climate Center, 2014). Using water years for comparison, water year 2005 precedes the October 2006 measurements, and water year 2011 precedes the 2012 measurements. At the Ketchum Ranger Station weather station, precipitation was $27.4 \mathrm{in}$. for water year 2005 and 13.6 in. for water year 2011, representing 152 and 76 percent of average annual precipitation, respectively. (The Ketchum Ranger Station lacked precipitation data for 35 days during water year 2011.) At the Picabo AgriMet weather station, precipitation was $13.1 \mathrm{in}$. for water year 2005 and 12.6 in. for water year 2011, which represented 106 and 102 percent of average annual precipitation, respectively. Thus, precipitation may have had an effect on water levels in the upper valley, but probably had no direct effect on water levels in the lower valley.

Less qualitatively, groundwater levels in areas that receive groundwater recharge from intermittent streams (including canals) or small streams that are highly sensitive to mountain precipitation tend to decline during dry periods because recharge is reduced. By assuming that discharge at the Big Wood River at Hailey streamgage (13139510, B05) (fig. 1) is an indicator of surface-water supply in the Wood River Valley, recharge from streams and canals prior to the 2006 and 2012 water-level measurements can be examined. The mean monthly August-October discharge at the Big Wood River at Hailey streamgage (13139510, B05) for 1915-2013 was $220 \mathrm{ft}^{3} / \mathrm{s}$. The mean monthly August-October discharge was $234 \mathrm{ft}^{3} / \mathrm{s}$ in 2006 and $175 \mathrm{ft}^{3} / \mathrm{s}$ in 2012, 106 and 79 percent, respectively, of the 1915-2013 August-October mean. Many canals south of Bellevue were dry by August 2012, confirming that recharge from canals was reduced prior to the October 2012 water-level measurement.

Groundwater levels in areas adjacent to perennial reaches of the Big Wood River or Silver Creek tend to fluctuate less because sufficient streamflow is available to recharge groundwater from losing stream reaches. The distribution of water-level declines in the unconfined aquifer is consistent with this pattern: declines are greatest in tributary canyons and areas of the Bellevue fan with canals or adjacent to the ephemeral reach of the Big Wood River. Moreland (1977, p. 22) noted that "Groundwater levels quickly decline after cessation of recharge from the river." The Wood River Valley north of Bellevue is narrow and the Big Wood River is well connected to the unconfined aquifer; water-level declines in this area typically are less than $2 \mathrm{ft}$. In addition to reducing groundwater recharge, the reduced supply of surface water for irrigation tends to increase groundwater pumping to make up the deficit. Therefore, decreases in surface-water supply prior to the October 2012 water-level measurement likely was partially responsible for 2006-12 water-level declines in the unconfined aquifer; the relative contribution of precipitation deficit and groundwater pumping to the declines is unknown.

Although the confined aquifer may not receive direct recharge from precipitation or streams, groundwater withdrawals from the confined aquifer induce flow into it from the unconfined aquifer. Water-table declines in the unconfined aquifer likely reduce the amount of water that flows into the confined aquifer. Therefore, groundwater withdrawals and declines in the water table of the unconfined aquifer likely are responsible for declines in the potentiometric surface of the confined aquifer.

Moreland (1977, p. 37) observed that the springs and seeps that provide the base flow at the Big Wood River at Stanton Crossing near Bellevue streamgage (13140800, B11) "probably are discharge points for the deep, confined aquifer." The shape of the 2012 potentiometric-surface suggests some discharge in this area (pl. 2). If there is discharge, the marked 2006-12 decline in the potentiometric surface in this area should have appreciably decreased winter 2012-13 discharge (base flow) at the streamgage; such a decrease is not readily apparent in the hydrograph for the streamgage, but statistical analysis is needed.

\section{Groundwater-Level Trends}

Caution should be exercised in using the 2006-12 groundwater-level change maps to identify water-level trends: two synoptic measurements 6 years apart may not accurately convey the direction or rate of water-level trends. Although the 2006-12 groundwater-level change maps shown on plates $2 B$ and 3 provide an overview of changes in the entire valley between two dates 6 years apart, an analysis of several wells with detailed temporal information can provide a basis for evaluation of these declines.

Five wells in and near the study area have semiannual water-level measurements that can be used to evaluate the changes shown on plates $2 B$ and 3 . Three of these wells with more than 50 years of record were evaluated for water-level trends in Skinner and others (2007): wells 2 (432657114144801, 01N 18E 01DAA1), 13 (432143114114301, 01S 19E 03CCB2), and C39 
(4320421141163801, 01S 18E 14AAB1) (fig. 1; pls. 1, 2 and [or] 3; and table B1). All three wells showed a statistically significant downward temporal trend in annual mean water levels. A fourth well, 69 (434104114241301, 04N 17E 14BBC1) (fig. 1; table B1; pls. 1 and 3), was not included in this earlier analysis because it had one waterlevel measurement in 1983, with no other measurements until semiannual measurements began in 1991. A fifth well, 431642114013002 (02S 20E 01ACC2), is about $4 \mathrm{mi}$ southeast of Picabo and outside the study area (fig. 1). For this report, temporal trends in water levels were evaluated for these five wells.

Water levels for the period of record from each of the five wells were evaluated with three nonparametric trend tests: seasonal Kendall tests using both two and four seasons, and Mann-Kendall tests on annual mean groundwater levels. Temporal trends were considered statistically significant if the p-value (or level of significance) was less than 0.005 at a confidence level at least 99.5 percent. The three tests for each of the five wells showed statistically significant trends. The temporal trend of water levels in well 69 was upward; trends in the remaining four wells were downward. Therefore, with the exception of well 69 near Warm Springs Creek and the well southeast of Picabo, temporal water-level trends agree with water-level changes shown on plates $1,2 B$, and 3 .

\section{Suggestions for the Groundwater-Level Network}

The greater accuracy of water-level change maps in this report (as compared to previous work and described in the section, "Change During October 2006-October 2012") allows qualitative evaluation of how well the existing network identifies areas of water-level change. The groundwater-level network would be enhanced by the addition or elimination of wells in specific areas, which would improve network ability to detect changes and would eliminate any unnecessary information redundancy. Specifically, fewer wells completed in the unconfined aquifer should be measured in the area between Hailey and Deer Creek, and in the area near the confluence of the Big Wood River and the East Fork Big Wood River because wells are in good communication with the Big Wood River, thus water levels exhibit little spatial variability in these areas (fig. 1; pls. 1 and 3). In some areas, low well density introduces uncertainty: unconfined aquifer wells should be added to the network in the main valley north of Ketchum, the area between Baseline and Glendale Roads, and the southwestern and southeastern parts of the Bellevue fan (fig. 1; pls. 1 and 3). Measurement of additional wells completed in the confined aquifer in the area east of Price Road would provide greater detail in an area of potentiometric-surface declines (pl. 2). If the number of wells in the network were to be increased, additional wells in the tributary canyons should be measured because they showed some of the largest water-level declines. Additional tributary canyon wells could also provide information on tributary underflow into the Wood River Valley aquifer system.

Because "water-level measurements from observation wells are the principal source of information about the hydrologic stresses acting on aquifers and how these stresses affect ground-water recharge, storage, and discharge," periodic measurement of water levels in the network is needed (Taylor and Alley, 2002, p. 1). The USGS and IDWR have measured four wells in the Wood River Valley since 1954 at intervals ranging from biweekly to semiannually. Measurement of these wells should continue and the larger network should be measured at 5-year intervals.

\section{Summary and Conclusions}

Stream-discharge measurements for determination of seepage were made during several days on three occasions: August 27-28, 2012, October 22-24, 2012, and March 27-28, 2013. Discharge measurements were made at 49 sites in August and October, and 51 sites in March, on the Big Wood River, Silver Creek, their tributaries, and nearby canals. The Big Wood River generally gains flow between the Big Wood River near Ketchum streamgage (13135500) and the Big Wood River at Hailey streamgage (13139510), and loses flow between the Hailey streamgage and the Big Wood River at Stanton Crossing near Bellevue streamgage (13140800). This spatial pattern of gaining and losing stream reaches was reasonably consistent throughout all three of the seasonal seepage investigations.

Water levels in 93 wells completed in the unconfined and confined aquifers of the Wood River Valley aquifer system were measured during October 22-24, 2012. Between October 2006 and October 2012, water-table altitude in the unconfined aquifer rose by as much as 1.86 feet in 6 wells and declined by as much as 14.28 feet in 77 wells; average decline was 2.9 feet. The largest declines were in tributary canyons and in an area roughly between Baseline and Glendale Roads. During the same period, the potentiometric-surface altitude in 10 wells completed in the confined aquifer declined between 0.12 and 20.50 feet; average decline was 6.8 feet. The largest declines were in the southwestern part of the Bellevue fan.

Reduced precipitation prior to the October 2012 water-level measurements likely is partially responsible for 2006-12 water-table declines in the unconfined aquifer; the relative contribution of precipitation deficit and groundwater withdrawals to the declines is not known. Declines in the confined aquifer are likely due to groundwater withdrawals and declines in the water table of the unconfined aquifer. A statistical analysis of five long-term monitoring wells (three completed in the unconfined aquifer, one in the confined aquifer, and one outside the aquifer system boundary) showed statistically significant declining trends in four wells. 


\section{Acknowledgments}

The author thanks Kevin Lakey, Watermaster of District 37, for technical advice and assistance. D.S. Ott of the USGS compiled the discharge measurements into initial seepage determinations. Sharon Lee and C.D. Sluder provided access to the Wood River through their respective properties; a number of well owners in the Wood River Valley graciously provided access to their wells. Technical discussions with Michael McVay, Jennifer Sukow, Sean Vincent, and Allan Wylie of the Idaho Department of Water Resources; and D.M. Evetts and J.C. Fisher of the U.S. Geological Survey provided insights on the data as well as the selection of discharge measurement sites. Members of the Wood River Valley Modeling Technical Advisory Committee offered suggestions that improved the report. Helpful technical reviews were provided by E.T. Fasser, and K.D. Skinner, both of the U.S. Geological Survey.

\section{References Cited}

Bartolino, J.R., 2009, Ground-water budgets for the Wood River Valley aquifer system, South-Central Idaho: U.S. Geological Survey Scientific Investigations Report 2009-5016, 36 p. [Also available at http://pubs.usgs. gov/sir/2009/5016/.]

Bartolino, J.R., and Adkins, C.B., 2012, Hydrogeologic framework of the Wood River Valley aquifer system, South-Central Idaho: U.S. Geological Survey Scientific Investigations Report 2012-5053, 46 p., 1 pl. in pocket. [Also available at http://pubs.usgs.gov/sir/2012/5053/.]

Berenbrock, C.E., Bassick, M.D., Rogers, T.L., and Garcia, S.P., 1995, Depth to water, 1991, in the Rathdrum Prairie, Idaho; Spokane River valley, Washington; Moscow-Lewiston-Grangeville area, Idaho; and selected intermontane valleys, east-central Idaho: U.S. Geological Survey Water-Resources Investigations Report 94-4087, scales $1: 250,000,1: 317,000,1: 500,000,3$ maps on 2 sheets. [Also available at http://pubs.er.usgs.gov/publication/ wri944087.]

Briar, D.W., Lawlor, S.M., Stone, M.A., Parliman, D.J., Schaefer, J.L., and Kendy, Eloise, 1996, Ground-water levels in intermontane basins of the northern Rocky Mountains, Montana and Idaho: U.S. Geological Survey Hydrologic Atlas 738-B, scale 1:750,000, 1 sheet. [Also available at http://pubs.er.usgs.gov/publication/ha738B.]
Brockway, C.E., and Grover, K.P., 1978, Evaluation of urbanization and changes in land use on the water resources of mountain valleys: Moscow, University of Idaho Water Resources Research Institute, 104 p. plus appendix. [Also available at http://contentdm.lib.uidaho.edu/u?/ idahowater,515.]

Brockway, C.E., and Kahlown, M.A., 1994, Hydrologic evaluation of the Big Wood River and Silver Creek watersheds Phase I: Kimberly, University of Idaho Water Resources Research Institute, Kimberly Research Center, 53 p. plus 5 appendixes. [Also available at http://contentdm. lib.uidaho.edu/u?/idahowater,406.]

Bureau of Reclamation, 2014, AgriMet Historical Archive Weather Data Access: Bureau of Reclamation database, accessed March 20, 2014, at http://www.usbr.gov/pn/ agrimet/webarcread.html.

Castelin, P.M., and Chapman, S.L., 1972, Water resources of the Big Wood River-Silver Creek area, Blaine County, Idaho: Boise, Idaho Department of Water Administration, Water Information Bulletin 28, 44 p. [Also available at http://www.idwr.idaho.gov/WaterInformation/Publications/.]

Castelin, P.M., and Winner, J.E., 1975, Effects of urbanization on the water resources of the Sun Valley-Ketchum area, Blaine County, Idaho: Boise, Idaho Department of Water Resources, Water Information Bulletin 40, 86 p. [Also available at http://www.idwr.idaho.gov/WaterInformation/ Publications/default.htm.]

Chapman, S.H., 1921, Water distribution and hydrometric work, Districts 7 and 11, Big and Little Wood Rivers: Shoshone, Idaho, Annual Report Watermaster Districts 7 and 11, 21 p., 67 charts.

Cunningham, W.L., and Schalk, C.W., comps., 2011, Groundwater technical procedures of the U.S. Geological Survey: U.S. Geological Survey Techniques and Methods 1-A1, $151 \mathrm{p}$. [Also available at http://pubs.usgs. gov $/ \mathrm{tm} / 1 \mathrm{a} 1 /$.]

Environmental Systems Research Institute, 2014, ArcGIS Help 10.1: Environmental Systems Research Institute Web site, accessed March 20, 2014, at http://resources.arcgis. $\mathrm{com} / \mathrm{en} / \mathrm{help} / \mathrm{main} / 10.1 /$ \#/Mapping_and_visualization_in ArcGIS_for_Desktop/018q00000004000000/.

Forstall, Richard, ed., 1995, Idaho population of counties by decennial census-1900 to 1990: U.S. Census Bureau, accessed March 20, 2014, at http://www.census.gov/ population/www/censusdata/cencounts/index.html. 
Frenzel, S.A., 1989, Water resources of the upper Big Wood River Basin, Idaho: U.S. Geological Survey WaterResources Investigations Report 89-4018, 47 p. [Also available at http://pubs.er.usgs.gov/pubs/wri/wri894018.]

Hansen, W.R., ed., 1991, Suggestions to authors of the reports of the United States Geological Survey, 7th ed.: U.S. Government Printing Office, 289 p., accessed May 20, 2014, at http://pubs.er.usgs.gov/publication/7000088.

Helsel, D.R., and Hirsch, R.M., 1992, Statistical methods in water resources: Amsterdam, Elsevier Science Publishers, $529 \mathrm{p}$.

Hopkins, C.B., and Bartolino, J.R., 2013, Quality of groundwater and surface water, Wood River Valley, south-central Idaho: U.S. Geological Survey Scientific Investigations Report 2013-5163, 32 p. [Also available at http://pubs.usgs.gov/sir/2013/5163/.]

Idaho Department of Water Resources, 2014a, Big Wood River Ground Water Management area: Idaho Department of Water Resources Web site, accessed March 20, 2014, at http:/www.idwr.idaho.gov/WaterInformation/ GroundWaterManagement/BigWoodRiver/bw_gwma.htm.

Idaho Department of Water Resources, 2014b, Preliminary order combining water districts in Basin 37 and inclusion of both surface and ground water rights in the combined water district; and abolishing the Upper Wood Rivers Water Measurement District: Idaho Department of Water Resources Web site, accessed March 20, 2014, at http:// www.idwr.idaho.gov/WaterManagement/WaterDistricts/ PDF/Camas_Wood/WD37_PrelimOrder_091713.pdf.

Idaho Water Resource Board, 1986, Idaho State Water Plan: Idaho Department of Water Resources, 42 p., accessed March 20, 2014, at http:/www.idwr.idaho.gov/waterboard/ WaterPlanning/Statewaterplanning/PDFs/SWP1986.pdf.

Jones, R.P., 1952, Evaluation of streamflow records in the Big Wood River Basin, Blaine County, Idaho: U.S. Geological Survey Circular 192, 59 p., 1 pl. in pocket. [Also available at http://pubs.er.usgs.gov/usgspubs/cir/cir192.]

Luttrell, S.P., and Brockway, C.E., 1984, Impacts of individual on-site sewage disposal facilities on mountain valleys-Phase II-Water-quality considerations: Moscow, University of Idaho, Idaho Water and Energy Resources Research Institute, Research Technical Completion Report WRIP/371403, 74 p. [Also available at http://contentdm.lib. uidaho.edu/u?/idahowater,428.]
Maupin, M.A., 1991, Depth to water in the western Snake River Plain and surrounding tributary valleys, southwestern Idaho and eastern Oregon, calculated using water levels from 1980 to 1988: U.S. Geological Survey Water-Resources Investigations Report 91-4020, scales $1: 1,000,000$ and 1:750,000, 2 maps on 1 sheet. [Also available at http://pubs.er.usgs.gov/usgspubs/wri/ wri914020.]

Maupin, M.A., 1992, Depth to water in the eastern Snake River Plain and surrounding tributary valleys, southwestern Idaho and eastern Oregon, calculated using water levels from 1980 to 1988: U.S. Geological Survey Water-Resources Investigations Report 90-4193, scales $1: 1,000,000$ and $1: 750,000,2$ maps on 1 sheet.

Moreland, J.A., 1977, Ground water-surface water relations in the Silver Creek area, Blaine County, Idaho: Boise, Idaho Department of Water Resources, Water Information Bulletin 44, 42 p., 5 pls. in pocket. [Also available at http://www. idwr.idaho.gov/WaterInformation/Publications/default. htm.] Also published as U.S. Geological Survey Open-File Report 77-456, 66 p., plates in pocket. [Also available at http://pubs.er.usgs.gov/pubs/ofr/ofr77456.]

Mueller, D.S., and Wagner, C.R., 2009, Measuring discharge with acoustic Doppler current profilers from a moving boat: U.S. Geological Survey Techniques and Methods, book 3, chap. A22, 72 p. [Also available at http://pubs.water.usgs. gov/tm3a22.]

Mundorff, M.J., Crosthwaite, E.G., and Kilburn, Chabot, 1964, Ground water for irrigation in the Snake River Basin in Idaho: U.S. Geological Water-Supply Paper 1654, 224 p., 6 pls. in pocket. [Also available at http://pubs.er.usgs.gov/ pubs/wsp/wsp1654.]

National Climatic Data Center, 2014, Daily summaries station details - Ketchum ranger station, ID, US: National Oceanic and Atmospheric Administration database, accessed March 20, 2014, at http:/www.ncdc.noaa.gov/cdo-web/datasets/ GHCND/stations/GHCND:USC00104845/detail.

Oberg, K.A., Morlock, S.E., and Caldwell, W.C., 2005, Quality-assurance plan for discharge measurements using acoustic Doppler current profilers: U.S. Geological Survey Scientific Investigations Report 2005-5183, 35 p. [Also available at http://pubs.usgs.gov/sir/2005/5183/.]

Powell, J.W., 1891, Eleventh annual report of the Director of the United States Geological Survey, Part 2-1889-1890: U.S. Geological Survey Annual Report 11, 390 p. [Also available at http://pubs.er.usgs.gov/publication/ar11_2.] 
Rantz, S.E., 1982, Measurement and computation of streamflow_Volume 2, Computation of discharge: U.S. Geological Water-Supply Paper 2175, 347 p. [Also available at http://pubs.usgs.gov/wsp/wsp2175/.]

Rantz, S.E., and others, 1982, Measurement and computation of streamflow-Volume 1, Measurement of stage and discharge: U.S. Geological Water-Supply Paper 2175, 284 p. [Also available at http://pubs.usgs.gov/wsp/ wsp2175/.]

Ross, D.W., 1903, Biennial report of the State Engineer to the Governor of Idaho, 1901-1902: Boise, Idaho, Statesman Print, p. 165-169.

Save Silver Creek, 2014, Current data list for temperature data, flow data and silt data: Save Silver Creek Web site, accessed March 20, 2014, at http://www.savesilvercreek. org.

Skinner, K.D., Bartolino, J.R., and Tranmer, A.W., 2007, Water-resource trends and comparisons between partial development and October 2006 hydrologic conditions, Wood River Valley, south-central Idaho: U.S. Geological Survey Scientific Investigations Report 2007-5258, 31 p., 4 pls., 1 appendix. [Also available at http://pubs.usgs.gov/ $\operatorname{sir} / 2007 / 5258 /$.

Smith, R.O., 1959, Ground-water resources of the middle Big Wood River-Silver Creek area, Blaine County, Idaho: U.S. Geological Survey Water-Supply Paper 1478, 61 p., 2 pls. [Also available at http://pubs.er.usgs.gov/usgspubs/wsp/ wsp1478.]

Smith, R.O., 1960, Geohydrologic evaluation of streamflow records in the Big Wood River Basin, Idaho: U.S. Geological Survey Water-Supply Paper 1479, 64 p., 4 pls. [Also available at http://pubs.er.usgs.gov/pubs/wsp/ wsp1479.]

SonTek/YSI, 2009, FlowTracker ${ }^{\circledR}$ handheld ADV technical manual, firmware version 3.7, software version 2.30: San Diego, California, SonTek/YSI, 116 p.

Stearns, H.T., Crandall, Lynn, and Steward, W.G., 1936, Records of wells on the Snake River Plain, in southeastern Idaho: U.S. Geological Survey Water-Supply Paper 775, 134 p. [Also available at http://pubs.er.usgs.gov/publication/ wsp775.]
Taylor C.J., and Alley, W.M., 2002, Ground-water-level monitoring and the importance of long-term water-level data (rev.): U.S. Geological Survey Circular 1217, 68 p. [Also available at http://pubs.usgs.gov/circ/circ1217/.]

Turnipseed, D.P., and Sauer, V.B., 2010, Discharge measurements at gaging stations: U.S. Geological Survey Techniques and Methods, book 3, chap. A8, 87 p. [Also available at http://pubs.usgs.gov/tm/tm3-a8/.]

U.S. Census Bureau, 2011, State and county quickfacts, Blaine County, Idaho: U.S Census Bureau Web site, accessed March 20, 2014, at http:/quickfacts.census.gov/qfd/ states/16/16013.html.

U.S. Environmental Protection Agency, 2013, Enforcement and compliance history online (ECHO): U.S. Environmental Protection Agency Web site, accessed March 20, 2014, at http://echo.epa.gov.

U.S. Geological Survey, 2014a, USGS Water Data for the Nation: U.S. Geological Survey Web site, accessed May 8, 2014, at http://waterdata.usgs.gov/nwis.

U.S. Geological Survey, 2014b, USGSwsStats - Statistic USGS water science R functions: GitHub Web site, accessed May 8, 2014, at https://github.com/USGS-R/ USGSwsStats.

Western Regional Climate Center, 2014, Idaho climate summaries: Western Regional Climate Center Web site, accessed March 20, 2014, at http:/www.wrcc.dri.edu/ summary/climsmid.html.

Wetzstein, A.B., Robinson, C.W., and Brockway, C.E., 2000, Hydrologic evaluation of the Big Wood River and Silver Creek watersheds, phase II: Kimberly, University of Idaho Water Resources Research Institute, Kimberly Research Center, 136 p. [Also available at http://contentdm.lib. uidaho.edu/u?/idahowater,412.]

Wheeler, J.D., and Eddy-Miller, C.A., 2005, Seepage investigation on selected reaches of Fish Creek, Teton County, Wyoming, 2004: U.S. Geological Survey Scientific Investigations Report 2005-5133, 22 p. [Also available at http://pubs.usgs.gov/sir/2005/5133/.] 


\section{Appendix A. Surface-Water Data}

Table A1. Summary of discharge measurements, measured streamflow gain or loss, and associated estimates of uncertainty on selected stream and canal reaches in the Wood River Valley, south-central Idaho, August 27-28, 2012.

[Site locations are shown in figure 2. Remarks: G, gaining reach; L, losing reach; U, difference in measured discharge in subreach is less than or equal to the associated measurement uncertainty; I, site inaccessible; N, not estimated due to lack of data; 5 , conventional meter: \pm 5 percent uncertainty; 8 , conventional meter: \pm 8 percent uncertainty; D, unaccounted for diversions; R, reported by Water District 37. Abbreviations: ID, Idaho; Rd., Road; NRA, National Recreation Area; $\mathrm{ft}^{3} / \mathrm{s}$, cubic foot per second; -, no value]

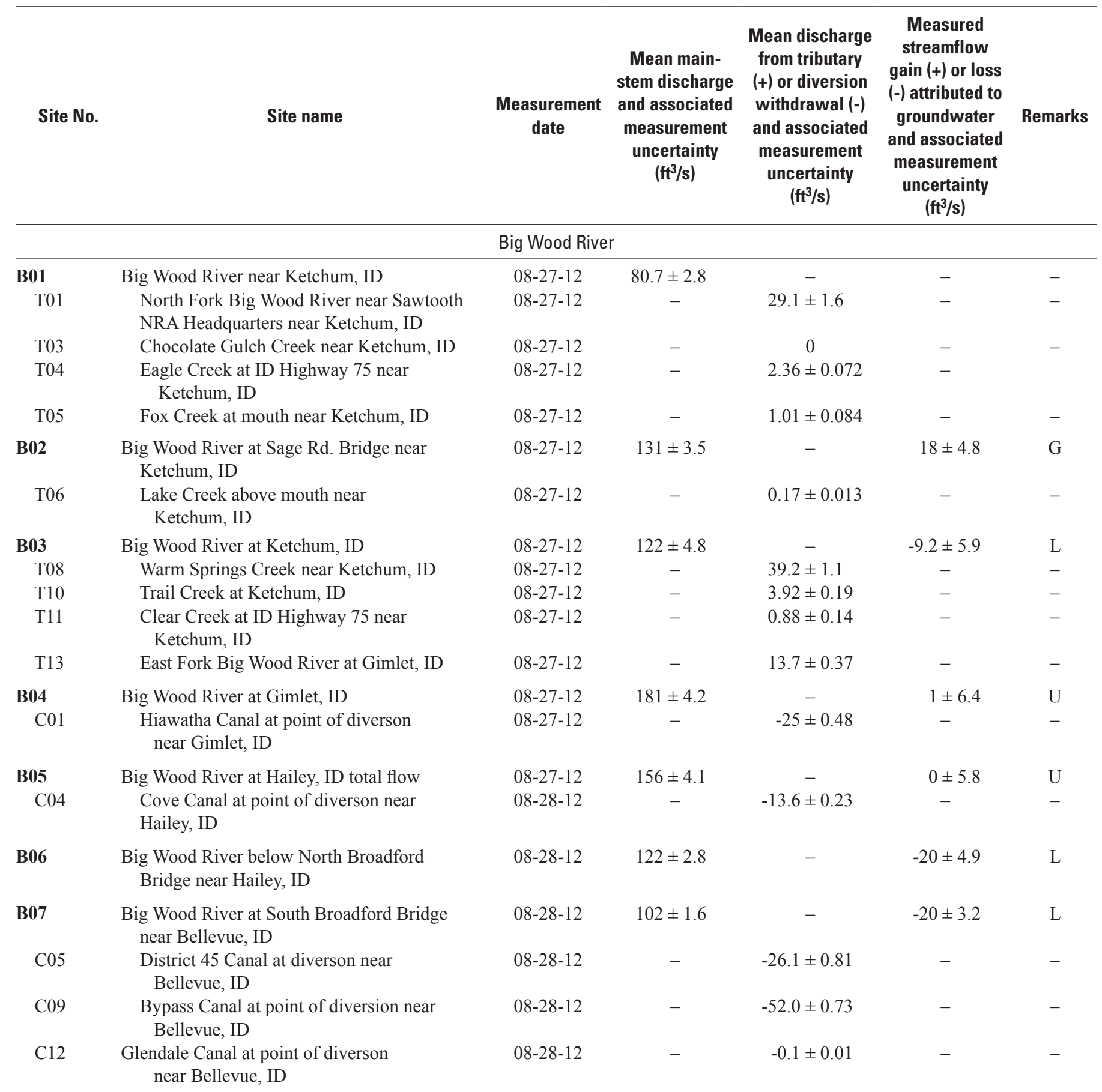


Table A1. Summary of discharge measurements, measured streamflow gain or loss, and associated estimates of uncertainty on selected stream and canal reaches in the Wood River Valley, south-central Idaho, August 27-28, 2012.—Continued

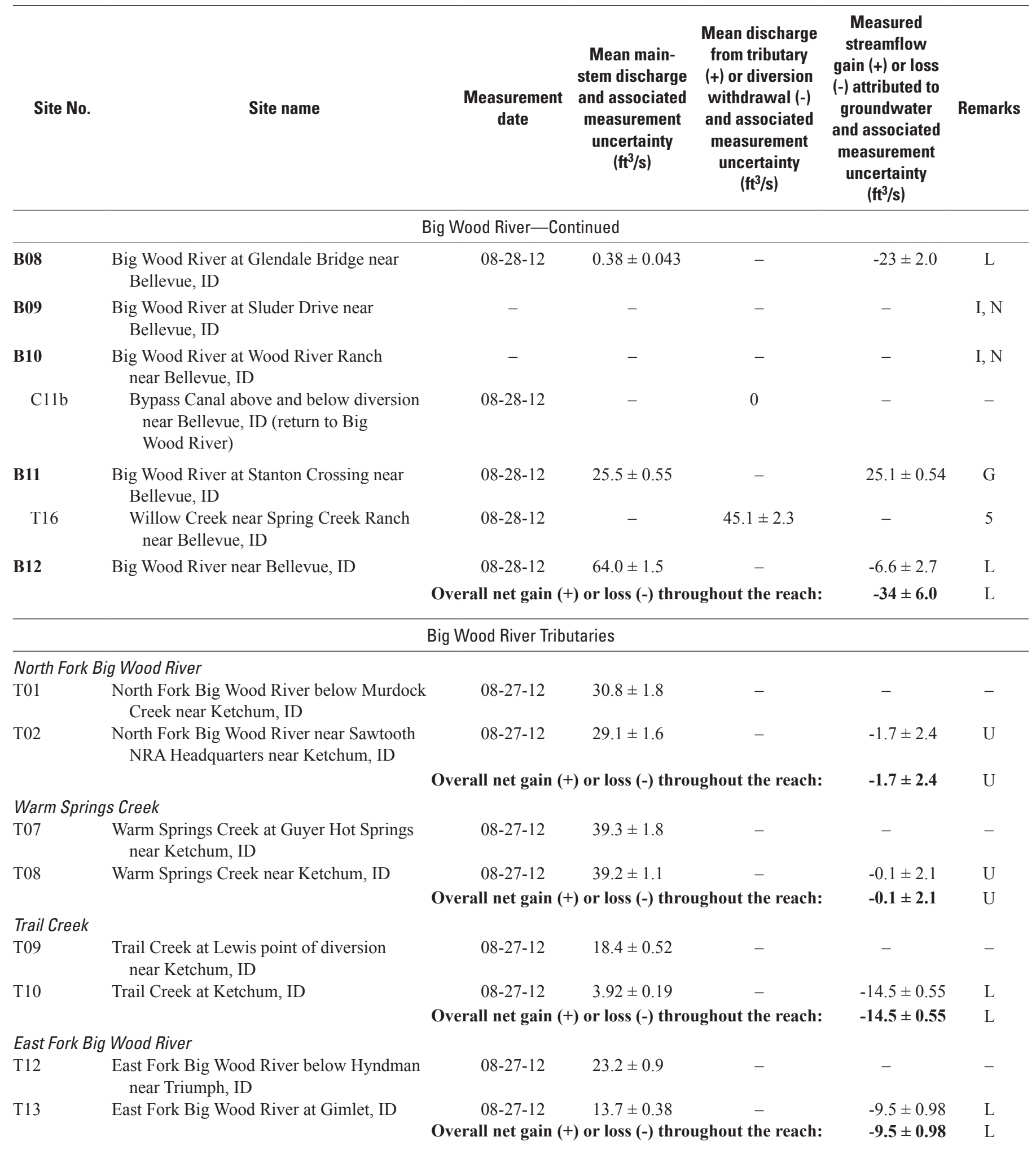


Table A1. Summary of discharge measurements, measured streamflow gain or loss, and associated estimates of uncertainty on selected stream and canal reaches in the Wood River Valley, south-central Idaho, August 27-28, 2012.—Continued

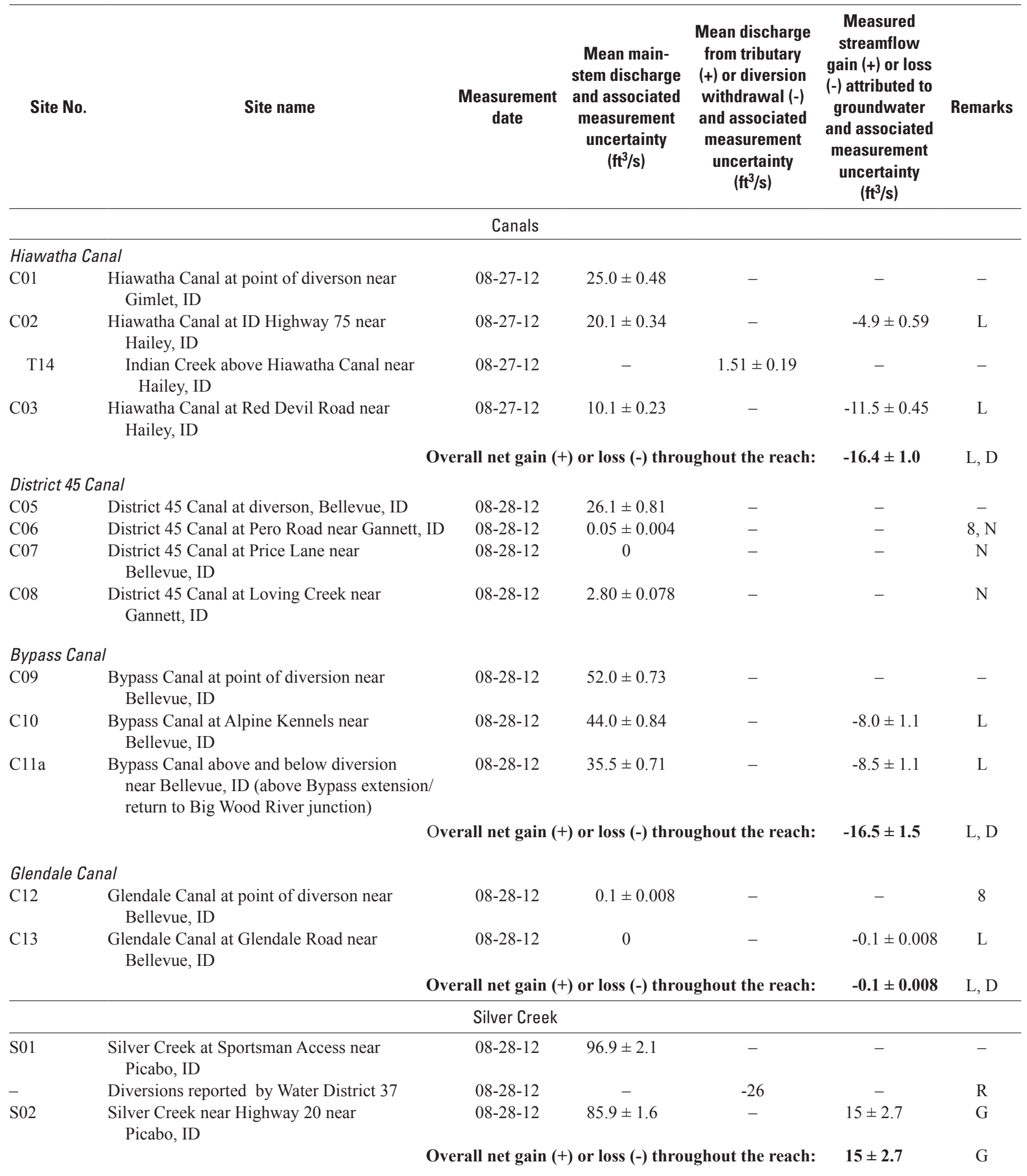




\section{Stream Seepage and Groundwater Levels, Wood River Valley, South-Central Idaho, 2012-13}

Table A1. Summary of discharge measurements, measured streamflow gain or loss, and associated estimates of uncertainty on selected stream and canal reaches in the Wood River Valley, south-central Idaho, August 27-28, 2012. - Continued

\begin{tabular}{|c|c|c|c|c|c|c|}
\hline Site No. & Site name & $\begin{array}{l}\text { Measurement } \\
\text { date }\end{array}$ & $\begin{array}{c}\text { Mean main- } \\
\text { stem discharge } \\
\text { and associated } \\
\text { measurement } \\
\text { uncertainty } \\
\left(\mathrm{ft}^{3} / \mathrm{s}\right)\end{array}$ & $\begin{array}{c}\text { Mean discharge } \\
\text { from tributary } \\
(+) \text { or diversion } \\
\text { withdrawal }(-) \\
\text { and associated } \\
\text { measurement } \\
\text { uncertainty } \\
\left(\mathrm{ft}^{3} / \mathrm{s}\right)\end{array}$ & $\begin{array}{c}\text { Measured } \\
\text { streamflow } \\
\text { gain (+) or loss } \\
(-) \text { attributed to } \\
\text { groundwater } \\
\text { and associated } \\
\text { measurement } \\
\text { uncertainty } \\
\left(\mathrm{ft}^{3} / \mathrm{s}\right)\end{array}$ & Remarks \\
\hline \multicolumn{7}{|c|}{ Miscellaneous measurements } \\
\hline \multicolumn{7}{|c|}{ Silver Creek Tributaries } \\
\hline R01 & $\begin{array}{l}\text { Butler Drain at US Highway } 20 \text { near } \\
\text { Gannett, ID }\end{array}$ & $08-28-12$ & $4.43 \pm 0.19$ & - & - & - \\
\hline R02 & $\begin{array}{l}\text { Patton Creek near US Highway } 20 \text { near } \\
\text { Gannett, ID }\end{array}$ & $08-28-12$ & $3.97 \pm 0.47$ & - & - & - \\
\hline R03 & $\begin{array}{l}\text { Cain Creek at US Highway } 20 \text { near } \\
\text { Gannett, ID }\end{array}$ & $08-28-12$ & $4.09 \pm 0.20$ & - & - & - \\
\hline R04 & $\begin{array}{l}\text { Chaney Creek at US Highway } 20 \text { near } \\
\text { Gannett }\end{array}$ & $08-28-12$ & $11.9 \pm 0.94$ & - & - & - \\
\hline R05 & $\begin{array}{l}\text { Mud Creek at US Highway } 20 \text { near } \\
\text { Gannett, ID }\end{array}$ & $08-28-12$ & $4.51 \pm 0.15$ & - & - & - \\
\hline R06 & $\begin{array}{l}\text { Wilson Creek at US Highway } 20 \text { near } \\
\text { Gannett, ID }\end{array}$ & $08-28-12$ & $10.1 \pm 0.58$ & - & - & - \\
\hline R07 & $\begin{array}{l}\text { Grove Creek at US Highway } 20 \text { near } \\
\text { Gannett, ID }\end{array}$ & $08-28-12$ & $43.1 \pm 0.69$ & - & - & - \\
\hline R08 & $\begin{array}{l}\text { Loving Creek at US Highway } 20 \text { near } \\
\text { Gannett. ID }\end{array}$ & $08-28-12$ & $22.1 \pm 0.49$ & - & - & - \\
\hline \multicolumn{7}{|c|}{ Seamans Creek } \\
\hline $\mathrm{T} 15$ & $\begin{array}{l}\text { Seamans Creek between ponds near } \\
\text { Bellevue, ID }\end{array}$ & $08-28-12$ & $1.74 \pm 0.17$ & - & - & 8 \\
\hline
\end{tabular}


Table A2. Summary of discharge measurements, measured streamflow gain or loss, and associated estimates of uncertainty on selected stream and canal reaches in the Wood River Valley, south-central Idaho, October 22-24, 2012.

[Site locations are shown in figure 2. Remarks: G, gaining reach; L, losing reach; U, difference in measured discharge in subreach is less than or equal to the associated measurement uncertainty; I, site inaccessible; N, not estimated due to lack of data; 5, conventional meter: \pm 5 percent uncertainty; 8 , conventional meter: \pm 8 percent uncertainty; D, unaccounted for diversions; R, reported by Water District 37. Abbreviations: ID, Idaho; Rd., Road; NRA, National Recreation Area; $\mathrm{ft}^{3} / \mathrm{s}$, cubic foot per second; -, no value]

\begin{tabular}{|c|c|c|c|c|c|c|}
\hline Site No. & Site name & $\begin{array}{l}\text { Measurement } \\
\text { date }\end{array}$ & $\begin{array}{l}\text { Mean main- } \\
\text { stem discharge } \\
\text { and associated } \\
\text { measurement } \\
\text { uncertainty } \\
\left(\mathrm{ft}^{3} / \mathrm{s}\right)\end{array}$ & $\begin{array}{c}\text { Mean discharge } \\
\text { from tributary } \\
(+) \text { or diversion } \\
\text { withdrawal (-) } \\
\text { and associated } \\
\text { measurement } \\
\text { uncertainty } \\
\left(\mathrm{ft}^{3} / \mathrm{s}\right)\end{array}$ & $\begin{array}{c}\text { Measured } \\
\text { streamflow } \\
\text { gain (+) or loss } \\
(-) \text { attributed to } \\
\text { groundwater } \\
\text { and associated } \\
\text { measurement } \\
\text { uncertainty } \\
\left(\mathrm{ft}^{3} / \mathrm{s}\right)\end{array}$ & Remarks \\
\hline \multicolumn{7}{|c|}{ Big Wood River } \\
\hline B01 & Big Wood River near Ketchum, ID & $10-22-12$ & $62.2 \pm 3.1$ & - & - & 5 \\
\hline T01 & $\begin{array}{l}\text { North Fork Big Wood River near Sawtooth } \\
\text { NRA Headquarters near Ketchum, ID }\end{array}$ & $10-22-12$ & - & $20.5 \pm 1.6$ & - & - \\
\hline T03 & Chocolate Gulch Creek near Ketchum, ID & $10-22-12$ & - & 0 & - & - \\
\hline B02 & $\begin{array}{l}\text { Big Wood River at Sage Rd. Bridge near } \\
\text { Ketchum, ID }\end{array}$ & $10-22-12$ & $98.8 \pm 4.0$ & - & $13 \pm 5.3$ & $\mathrm{U}$ \\
\hline T06 & $\begin{array}{l}\text { Lake Creek above mouth near } \\
\text { Ketchum, ID }\end{array}$ & $10-22-12$ & - & $0.060 \pm 0.011$ & - & - \\
\hline B03 & Big Wood River at Ketchum, ID & $10-22-12$ & $97.4 \pm 2.0$ & - & $-1.5 \pm 4.4$ & $\mathrm{U}$ \\
\hline T08 & Warm Springs Creek near Ketchum, ID & $10-22-12$ & - & $39.2 \pm 2.0$ & - & 5 \\
\hline $\mathrm{T} 10$ & Trail Creek at Ketchum, ID & $10-23-12$ & - & $12.8 \pm 1.0$ & - & 8 \\
\hline $\mathrm{T} 11$ & $\begin{array}{l}\text { Clear Creek at ID Highway } 75 \text { near } \\
\text { Ketchum, ID }\end{array}$ & $10-22-12$ & - & $1.13 \pm 0.066$ & - & - \\
\hline $\mathrm{T} 13$ & East Fork Big Wood River at Gimlet, ID & $10-22-12$ & - & $15.0 \pm 0.32$ & - & - \\
\hline B04 & Big Wood River at Gimlet, ID & $10-22-12$ & $185 \pm 3.3$ & & $19 \pm 4.5$ & $\mathrm{G}$ \\
\hline B07 & $\begin{array}{l}\text { Big Wood River at South Broadford Bridge } \\
\text { near Bellevue, ID }\end{array}$ & $10-23-12$ & $149 \pm 2.5$ & - & $-17 \pm 3.4$ & $\mathrm{~L}$ \\
\hline $\mathrm{C} 05$ & $\begin{array}{l}\text { District } 45 \text { Canal at diverson near } \\
\text { Bellevue, ID }\end{array}$ & $10-23-12$ & - & $-0.43 \pm 0.022$ & - & - \\
\hline $\mathrm{C} 09$ & $\begin{array}{l}\text { Bypass Canal at point of diversion near } \\
\text { Bellevue, ID }\end{array}$ & $10-23-12$ & - & $-128 \pm 1.8$ & - & - \\
\hline $\mathrm{C} 12$ & $\begin{array}{l}\text { Glendale Canal at point of diverson } \\
\text { near Bellevue, ID }\end{array}$ & $10-23-12$ & - & $-0.1 \pm 0.008$ & - & 8 \\
\hline
\end{tabular}


Table A2. Summary of discharge measurements, measured streamflow gain or loss, and associated estimates of uncertainty on selected stream and canal reaches in the Wood River Valley, south-central Idaho, October 22-24, 2012.-Continued

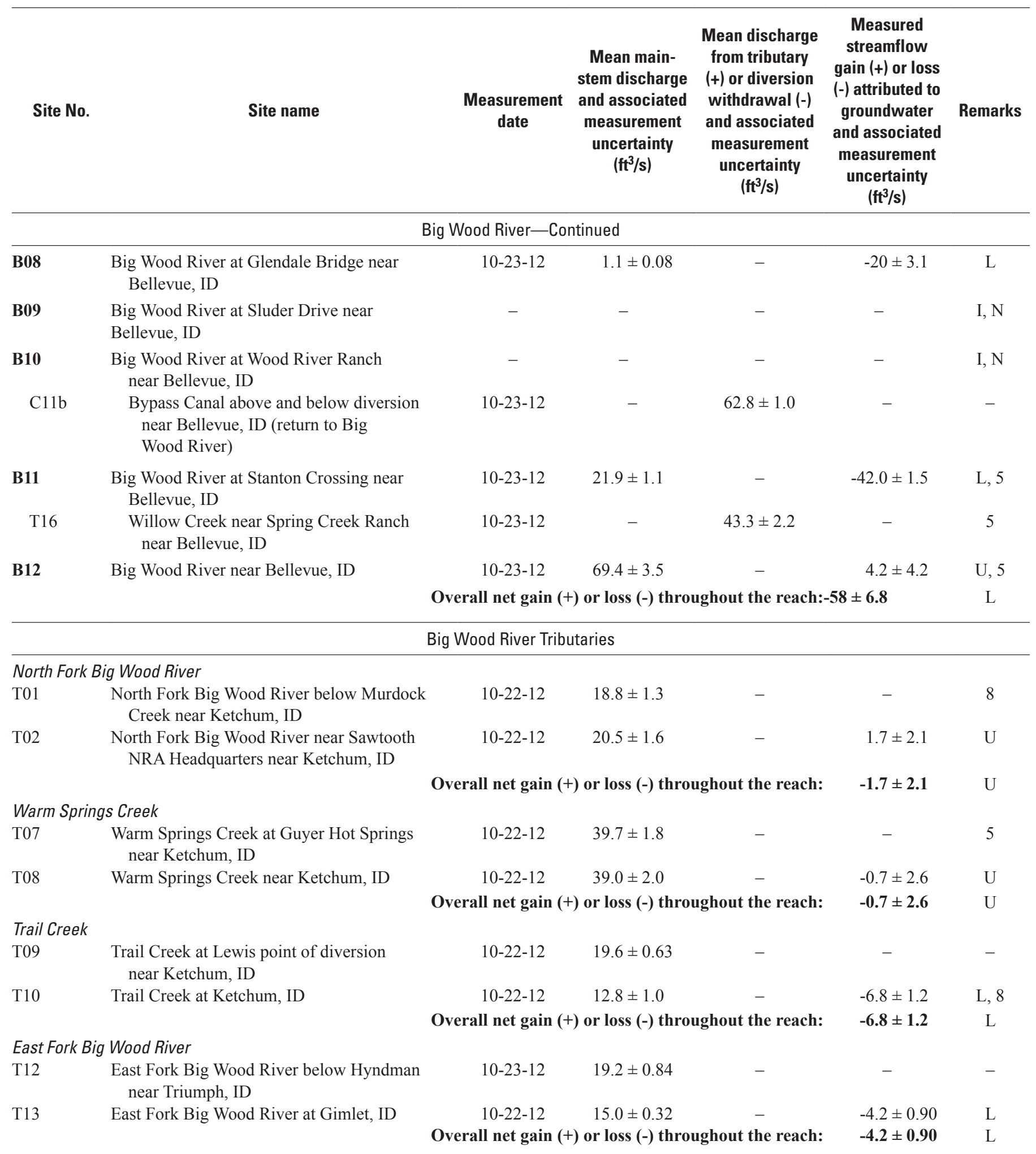


Table A2. Summary of discharge measurements, measured streamflow gain or loss, and associated estimates of uncertainty on selected stream and canal reaches in the Wood River Valley, south-central Idaho, October 22-24, 2012.-Continued

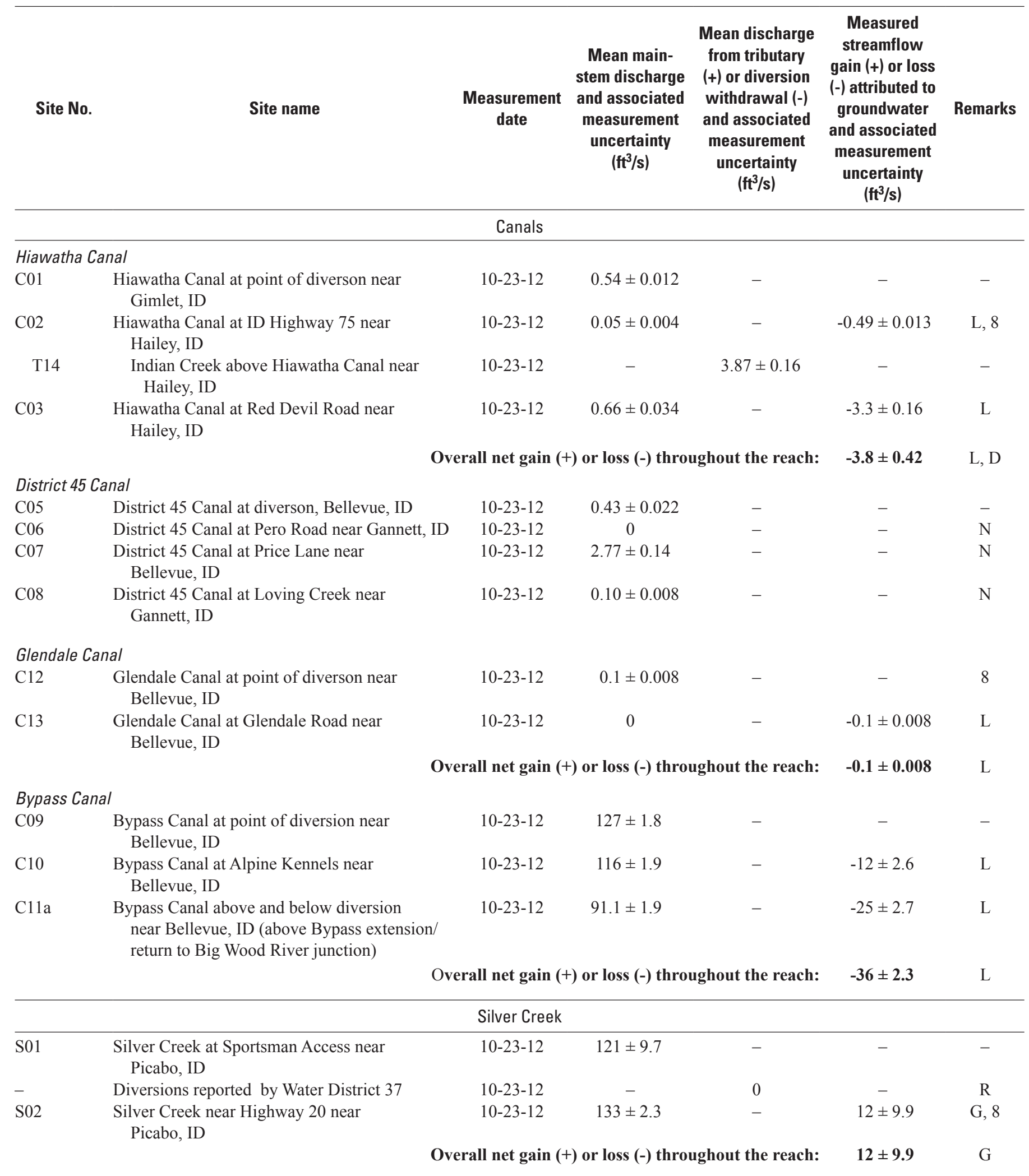


Table A2. Summary of discharge measurements, measured streamflow gain or loss, and associated estimates of uncertainty on selected stream and canal reaches in the Wood River Valley, south-central Idaho, October 22-24, 2012.—Continued

\begin{tabular}{|c|c|c|c|c|c|c|}
\hline Site No. & Site name & $\begin{array}{l}\text { Measurement } \\
\text { date }\end{array}$ & $\begin{array}{l}\text { Mean main- } \\
\text { stem discharge } \\
\text { and associated } \\
\text { measurement } \\
\text { uncertainty } \\
\left(\mathrm{ft}^{3} / \mathrm{s}\right)\end{array}$ & $\begin{array}{c}\text { Mean discharge } \\
\text { from tributary } \\
(+) \text { or diversion } \\
\text { withdrawal (-) } \\
\text { and associated } \\
\text { measurement } \\
\text { uncertainty } \\
\left(\mathrm{ft}^{3} / \mathrm{s}\right)\end{array}$ & $\begin{array}{c}\text { Measured } \\
\text { streamflow } \\
\text { gain (+) or loss } \\
\text { (-) attributed to } \\
\text { groundwater } \\
\text { and associated } \\
\text { measurement } \\
\text { uncertainty } \\
\left(\mathrm{ft}^{3} / \mathrm{s}\right)\end{array}$ & Remarks \\
\hline \multicolumn{7}{|c|}{ Miscellaneous measurements } \\
\hline \multicolumn{7}{|c|}{ Silver Creek Tributaries } \\
\hline R01 & $\begin{array}{l}\text { Butler Drain at US Highway } 20 \text { near } \\
\text { Gannett, ID }\end{array}$ & $10-23-12$ & $1.29 \pm 0.075$ & - & - & - \\
\hline R02 & $\begin{array}{l}\text { Patton Creek near US Highway } 20 \text { near } \\
\text { Gannett, ID }\end{array}$ & $10-24-12$ & $0.82 \pm 0.054$ & - & - & - \\
\hline R03 & $\begin{array}{l}\text { Cain Creek at US Highway } 20 \text { near } \\
\text { Gannett, ID }\end{array}$ & $10-23-12$ & $1.75 \pm 0.23$ & - & - & - \\
\hline R04 & $\begin{array}{l}\text { Chaney Creek at US Highway } 20 \text { near } \\
\text { Gannett }\end{array}$ & $10-24-12$ & $10.8 \pm 0.46$ & - & - & - \\
\hline R05 & $\begin{array}{l}\text { Mud Creek at US Highway } 20 \text { near } \\
\text { Gannett, ID }\end{array}$ & $10-23-12$ & $4.52 \pm 0.13$ & - & - & - \\
\hline R06 & $\begin{array}{l}\text { Wilson Creek at US Highway } 20 \text { near } \\
\text { Gannett, ID }\end{array}$ & $10-24-12$ & $10.5 \pm 0.60$ & - & - & - \\
\hline R07 & $\begin{array}{l}\text { Grove Creek at US Highway } 20 \text { near } \\
\text { Gannett, ID }\end{array}$ & $10-23-12$ & $35.0 \pm 0.67$ & - & - & - \\
\hline R08 & $\begin{array}{l}\text { Loving Creek at US Highway } 20 \text { near } \\
\text { Gannett. ID }\end{array}$ & $10-23-12$ & $29.9 \pm 0.69$ & - & - & - \\
\hline \multicolumn{7}{|c|}{ Seamans Creek } \\
\hline T15 & $\begin{array}{l}\text { Seamans Creek between ponds near } \\
\text { Bellevue, ID }\end{array}$ & $10-23-12$ & $2.00 \pm 0.16$ & - & - & 8 \\
\hline
\end{tabular}


Table A3. Summary of discharge measurements, measured streamflow gain or loss, and associated estimates of uncertainty on selected stream and canal reaches in the Wood River Valley, south-central Idaho, March 27-28, 2013.

[Site locations are shown in figure 2. Remarks: G, gaining reach; L, losing reach; U, difference in measured discharge in subreach is less than or equal to the associated measurement uncertainty; I, site inaccessible; $\mathrm{N}$, not estimated due to lack of data; 5 , conventional meter: \pm 5 percent uncertainty; 8 , conventional meter: \pm 8 percent uncertainty; R, reported by Water District 37. Abbreviations: ID, Idaho; Rd., Road; NRA, National Recreation Area; $\mathrm{ft}^{3} / \mathrm{s}, \mathrm{cubic} \mathrm{foot}_{\mathrm{fer}}$ second; -, no value]

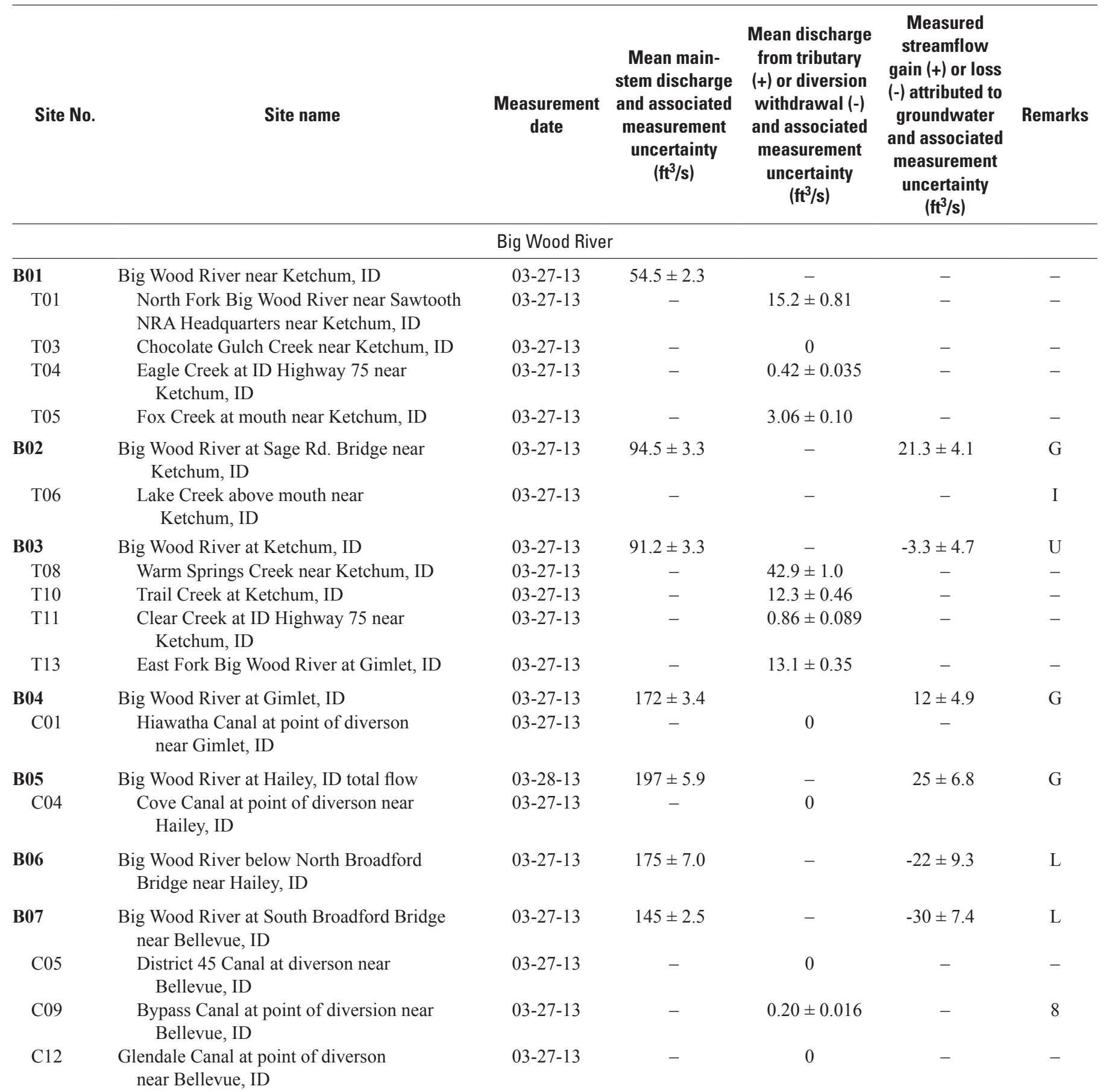


Table A3. Summary of discharge measurements, measured streamflow gain or loss, and associated estimates of uncertainty on selected stream and canal reaches in the Wood River Valley, south-central Idaho, March 27-28, 2013.—Continued

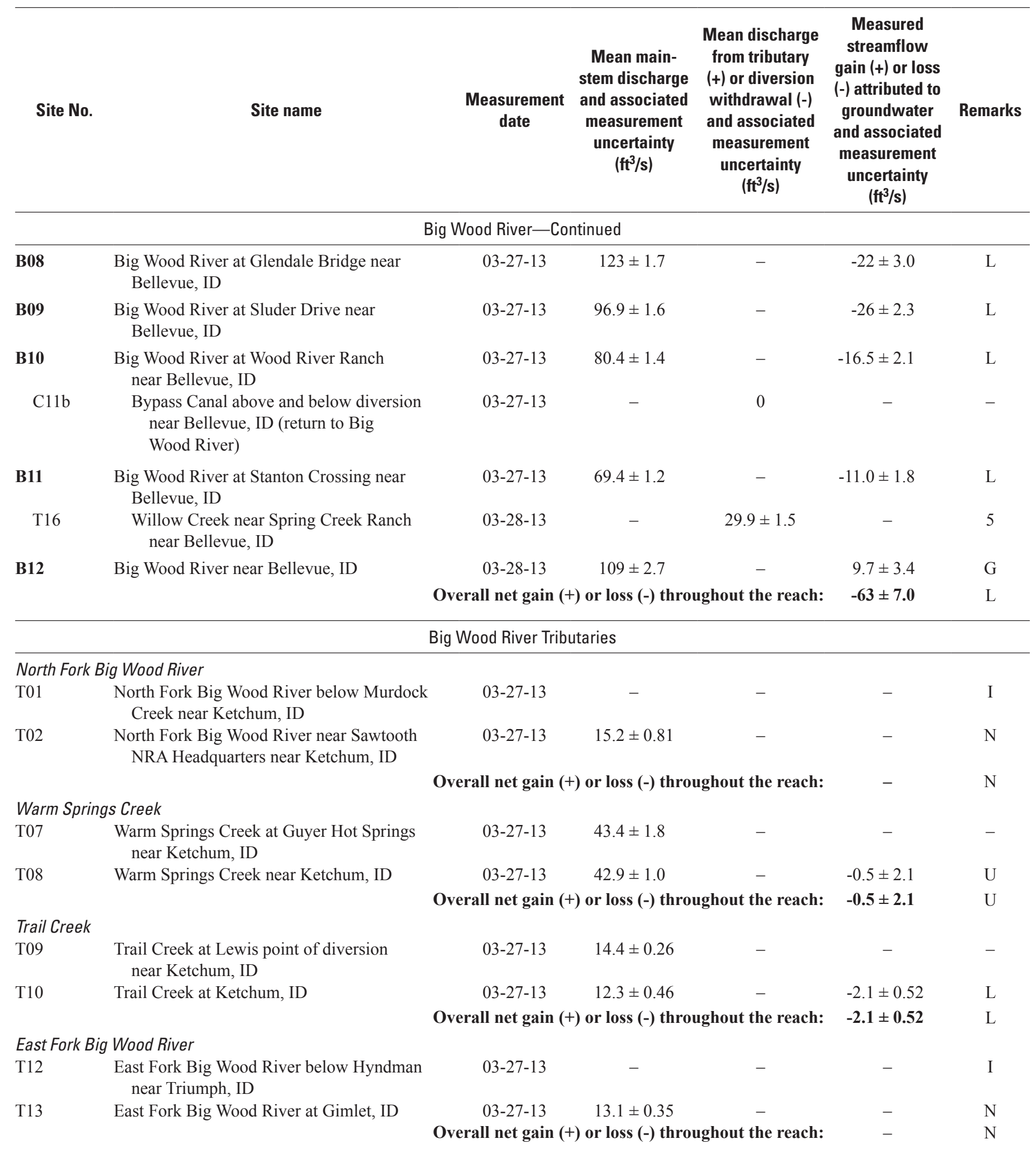


Table A3. Summary of discharge measurements, measured streamflow gain or loss, and associated estimates of uncertainty on selected stream and canal reaches in the Wood River Valley, south-central Idaho, March 27-28, 2013. - Continued

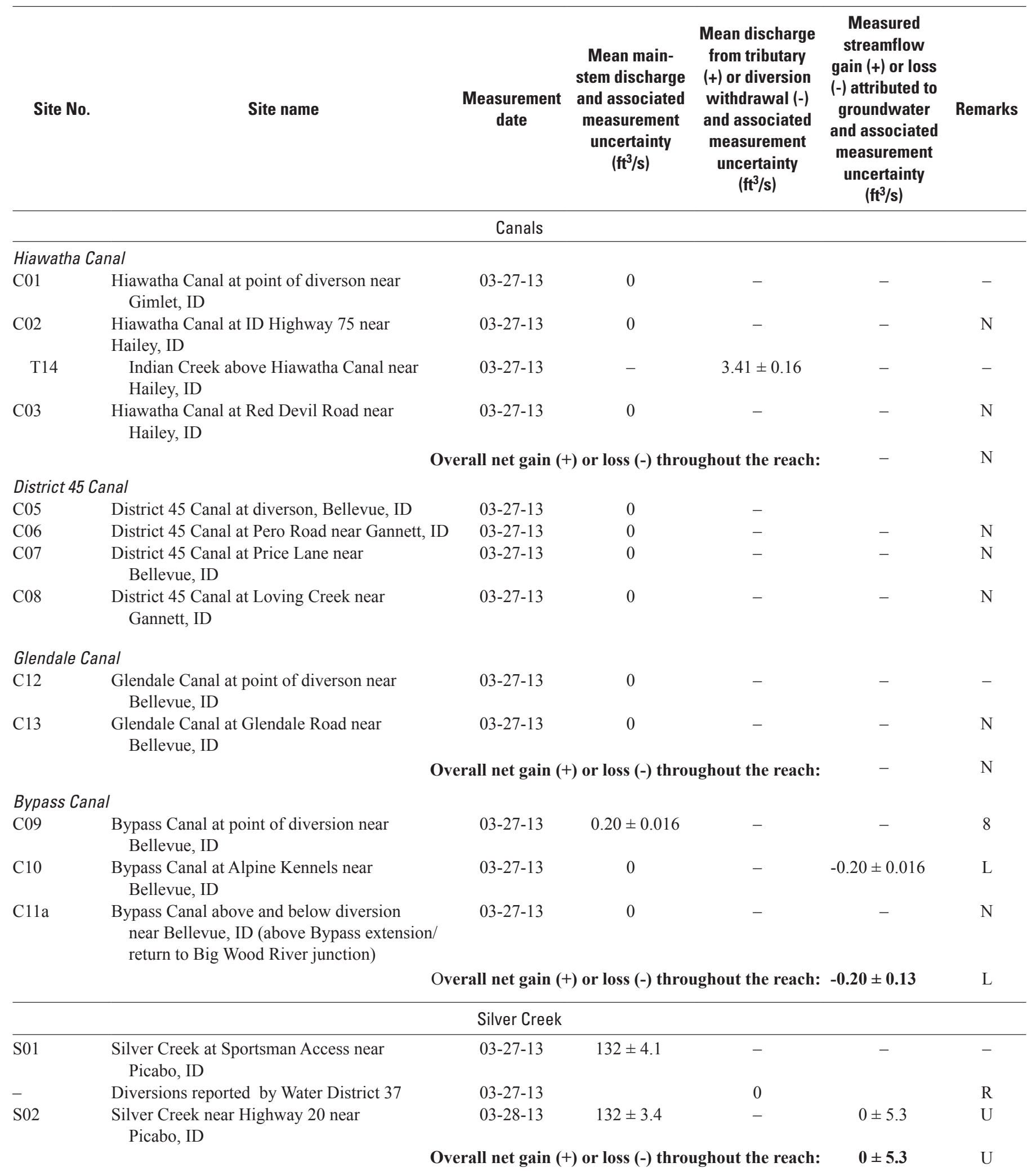


Table A3. Summary of discharge measurements, measured streamflow gain or loss, and associated estimates of uncertainty on selected stream and canal reaches in the Wood River Valley, south-central Idaho, March 27-28, 2013.—Continued

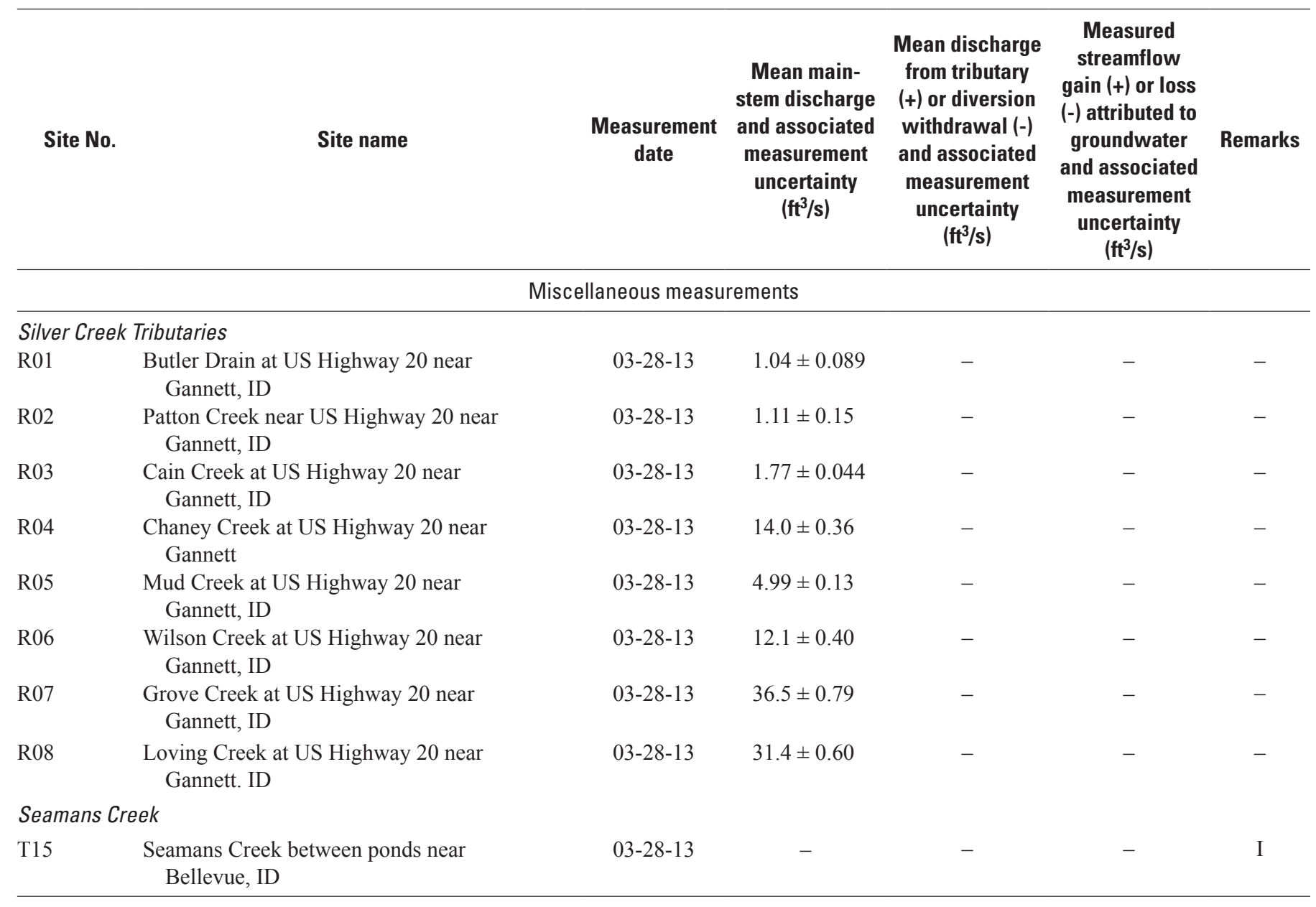




\section{Appendix B. Groundwater Data}




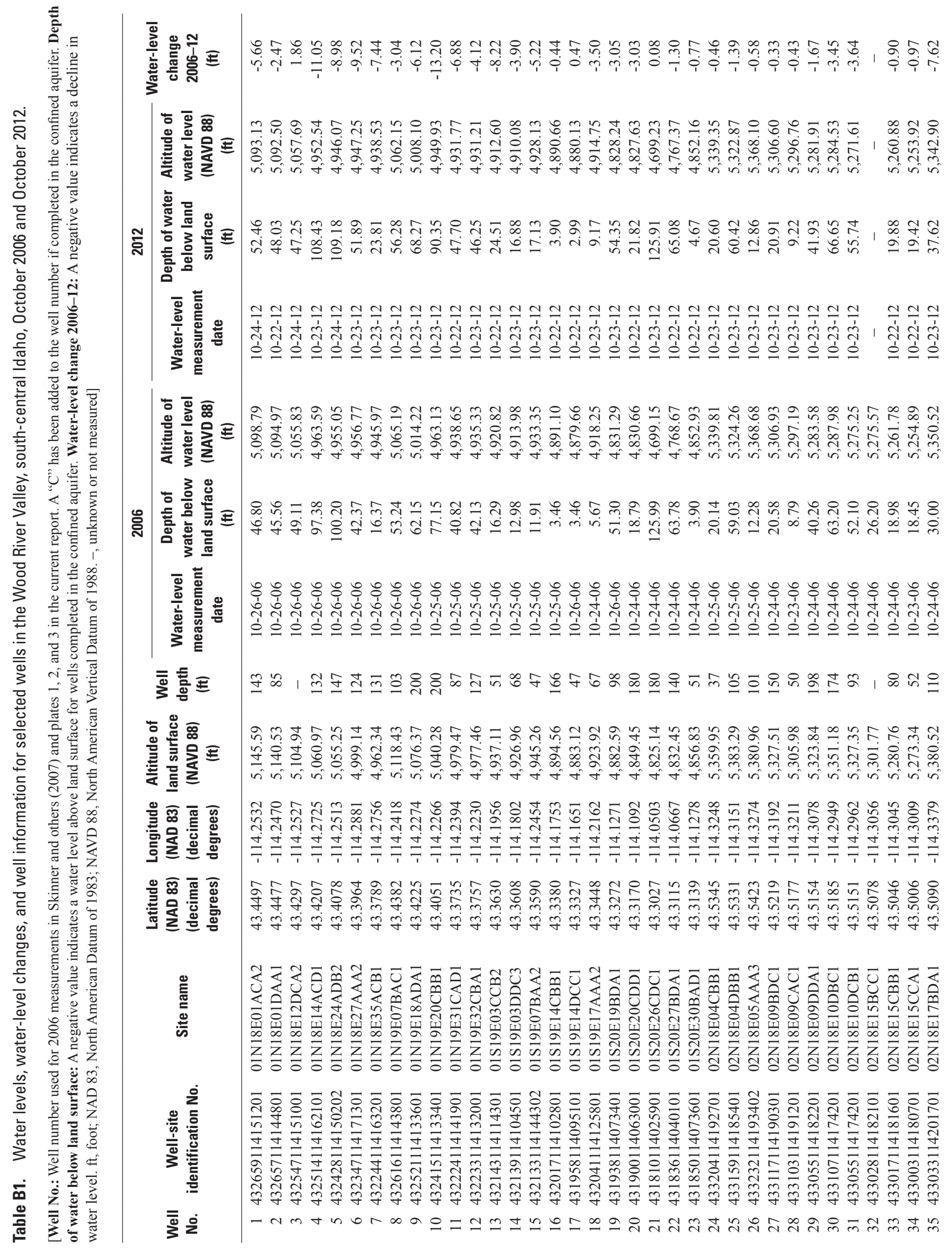


ஸे

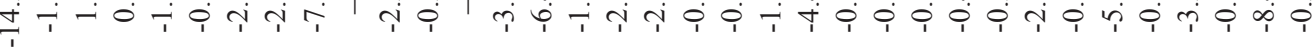

ஜ

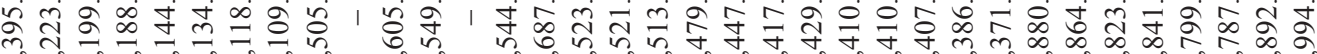

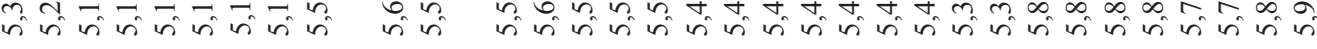

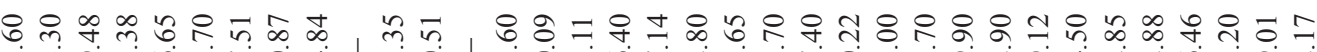
तों कें

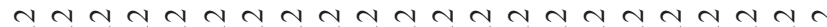

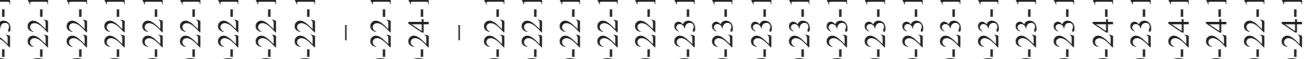

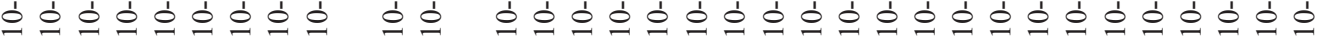

๓

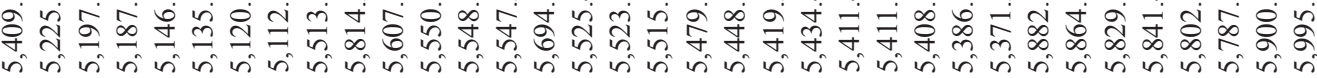

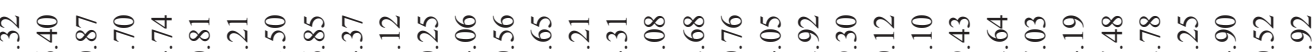

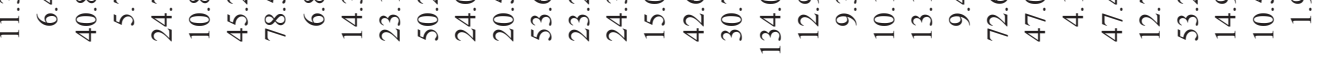
৪ ৪ ৪ ৪ ৪ ৪ ৪ ৪ ৪ ৪ ৪ ৪ ৪ ৪ ৪ ৪ ৪ ৪ ৪ ৪ ৪

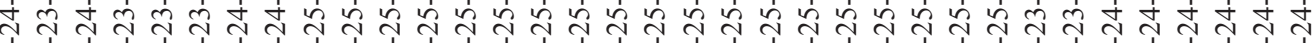
응ㅇㅇㅇㅇㅇㅇㅇㅇㅇㅇㅇㅇㅇㅇㅇㅇㅇㅇㅇㅇㅇㅇㅇㅇㅇㅇㅇㅇㅇㅇㅇㅇㅇㅇㅇㅇㅇㅇㅇㅇㅇㅇㅇㅇ

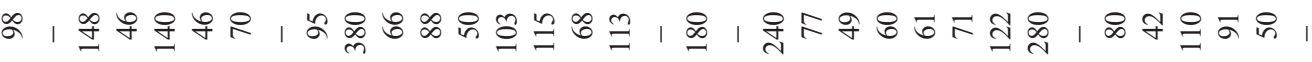
뜨스의 ᄀु

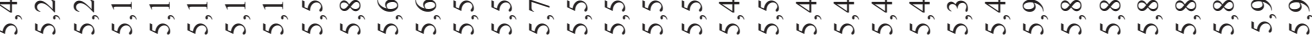

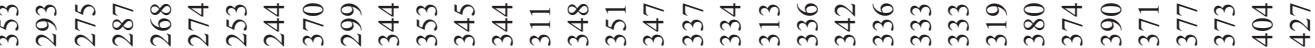

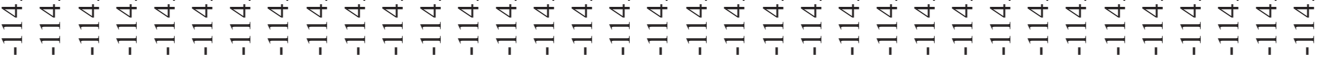

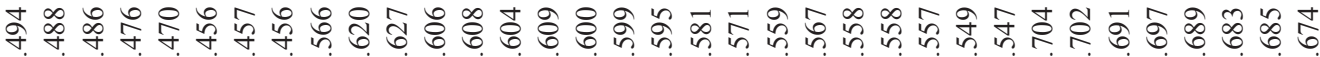

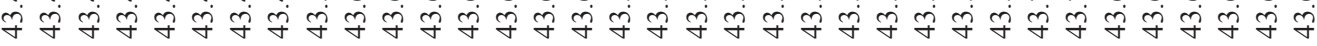

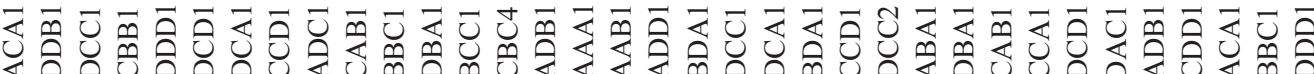
行沓过

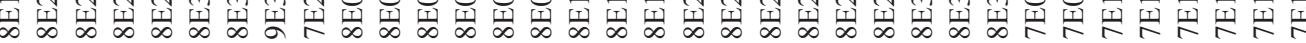

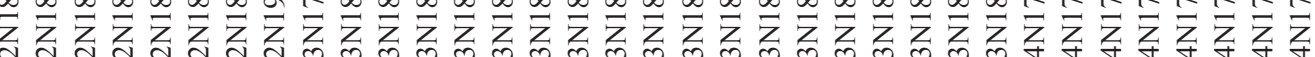

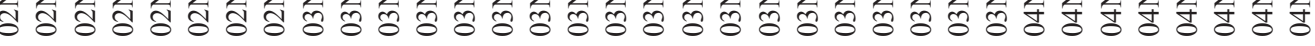

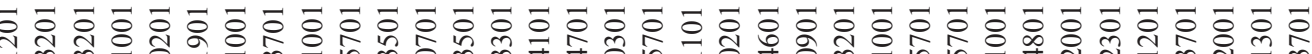

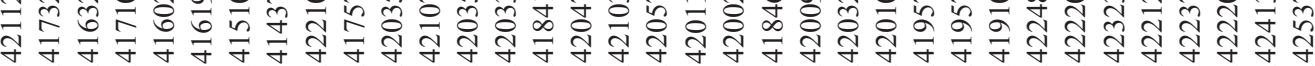

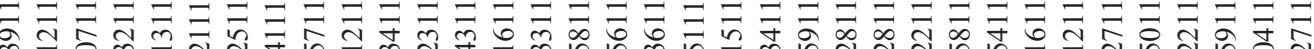

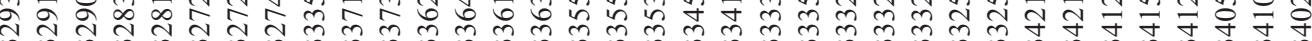

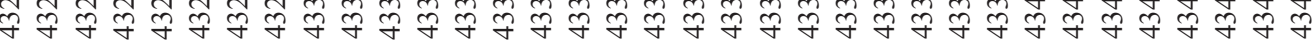

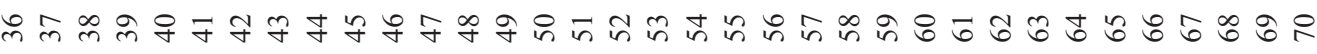




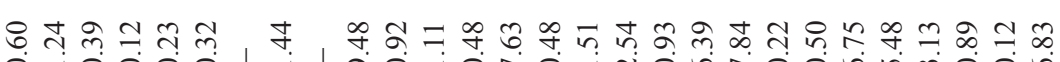

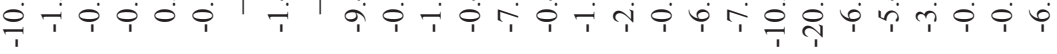
흐의 哃

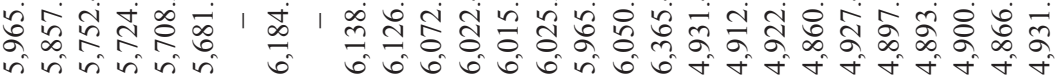

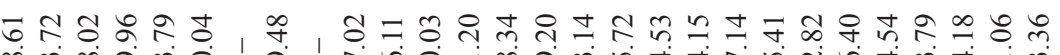
क्षें

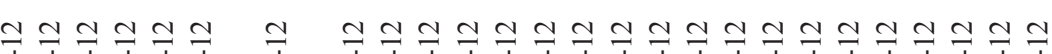

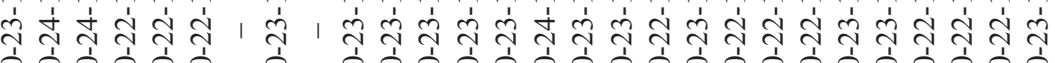
으응ㅇㅇㅇㅇㅇㅇㅇㅇㅇㅇㅇㅇㅇㅇㅇㅇㅇㅇㅇㅇㅇㅇㅇㅇㅇㅇㅇㅇㅇㅇㅇㅇ

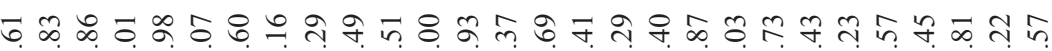

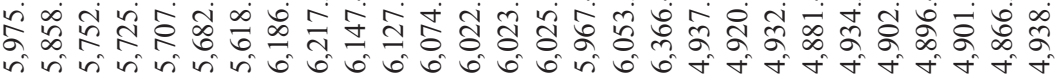
舟

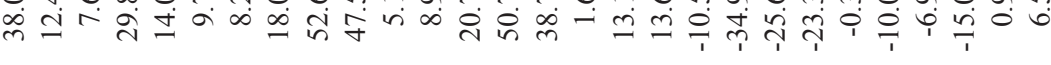

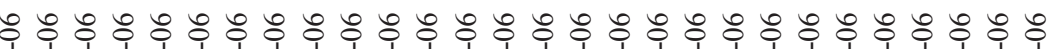

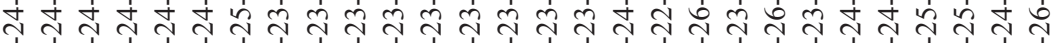
응ㅇㅇㅇㅇㅇㅇㅇㅇㅇㅇㅇㅇㅇㅇㅇㅇㅇㅇㅇㅇㅇㅇㅇㅇㅇㅇㅇㅇㅇㅇㅇㅇㅇㅇㅇㅇㅇㅇ

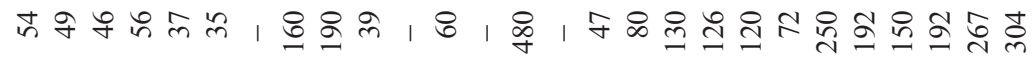

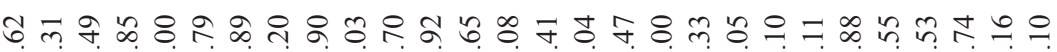

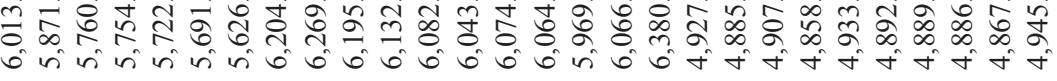
क n

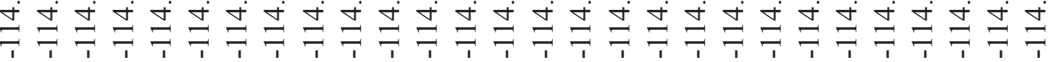

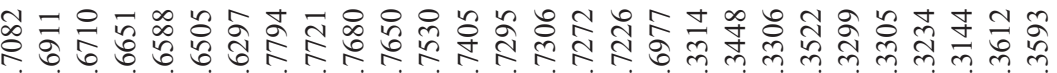

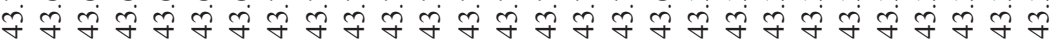
安导谣论

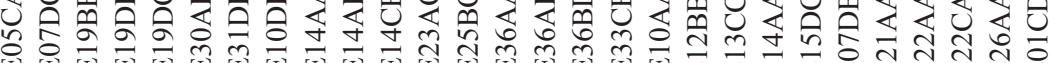

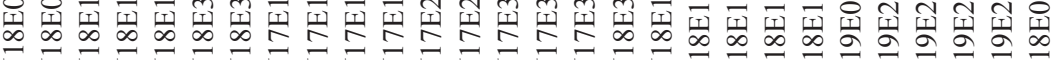

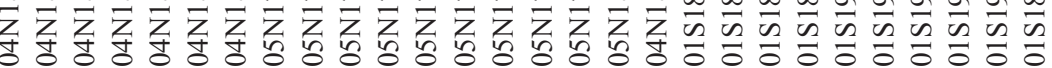

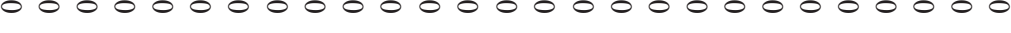

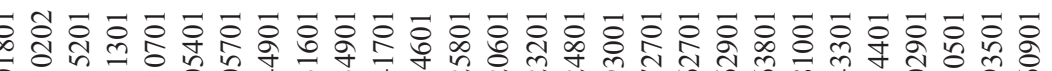

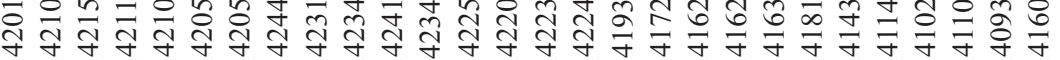

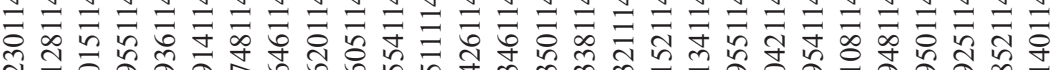

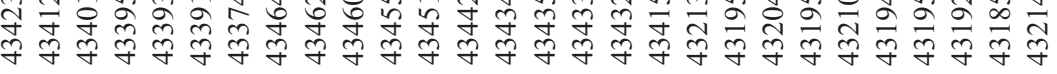

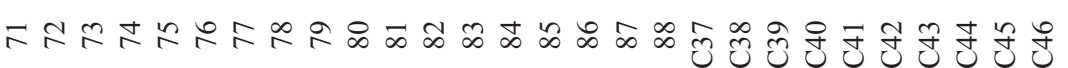


Publishing support provided by the U.S. Geological Survey Science Publishing Network, Tacoma Publishing Service Center

For more information concerning the research in this report, contact the Director, Idaho Water Science Center

U.S. Geological Survey

230 Collins Road

Boise, Idaho 83702

http://id.water.usgs.gov 


\section{हू}

ర్య

을

$\infty$

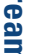

es

ํㅗㅇ

ํㅡㄹ

$\frac{2}{9}$

일

$\sum^{2}$

㞼

胥

$\frac{\Phi}{\infty}$

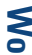

음

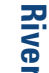

需

$\stackrel{\overline{0}}{\leftarrow}$

\&

字

$\stackrel{\Phi}{=}$

흘

亨

ज

cos

䍐

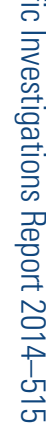

